

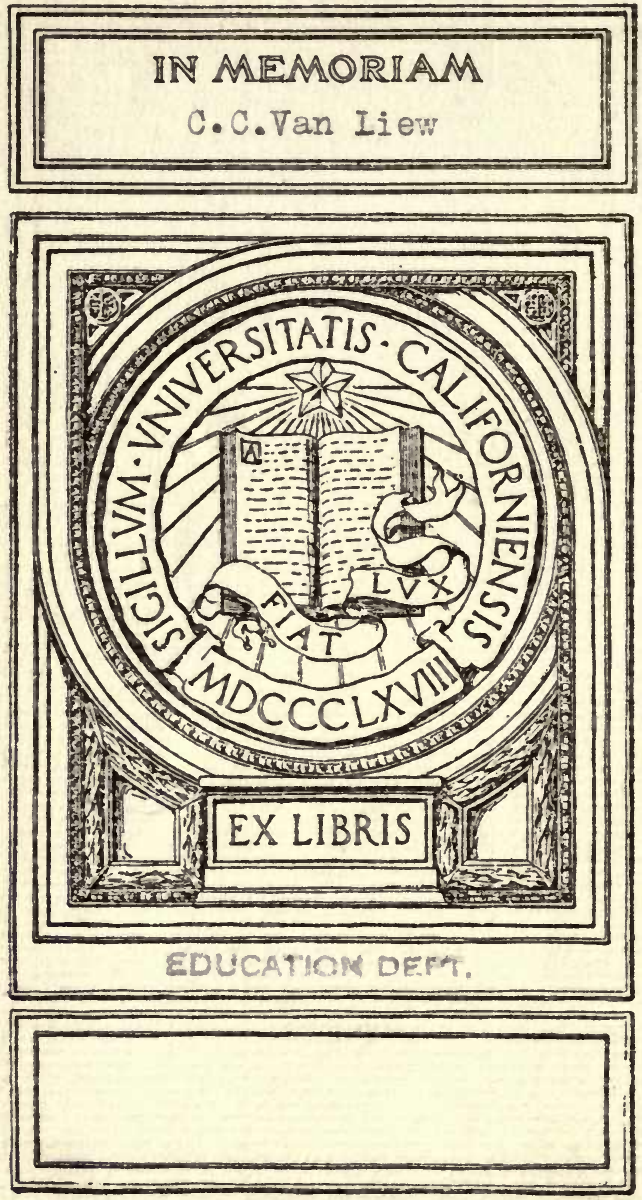




\title{
NATURE STUDY LESSONS
}

\author{
FOR PRIMARY GRADES
}





\section{NATURE STUDY LESSONS}

\section{FOR PRIMARY GRADES}

BY

MRS. LIDA B. MCMURRY

WITH AN INTRODUCTION

BY

CHARLES A. MCMURRY

Noxw 19atk

\section{THE MACMILLAN COMPANY}

LONDON: MACMILLAN \& CO., LTD.

1905 


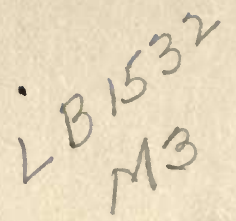

COPYRIGHT, Ig05,

By THE MACMILLAN COMPANY.

Set up and electrotyped. Published May, $x 905$.

EDHCATIOH DEPT. 


\section{PREFACE}

THE series of nature study lessons furnished in this book was worked out in the class room and in outdoor excursions with children.

Most of the lessons are studies of plant and animal life as it presents itself in one locality; but the objects studied are found in most temperate regions, and the lessons can be modified to suit almost any region of the United States.

The method of treatment is also somewhat fully indicated by questions and answers. These work out more fully the plan for primary grades outlined in the "Special Method in Elementary Science," which also contains full references to the best books and helps for primary grades.

Many of these lessons were originally published as a part of the first edition of the "Special Method in Elementary Science." But the series of lessons is now enlarged and published separately. 



\section{CONTENTS}

PAGE

INTRODUCTION • • • • • • • • • ix

PART I. ANIMAL LIFE

I. The Shepherd Dog • • • • - 3

II. The CAt • • • • • • • • 13

III. THE HORSE $•$ - . . . . . 19

IV. THE Cow . . . . . . . 30

V. The Sheep. • • • • . . . 37

VI. The Fox SquirRel • • • • • 43

VII. The Life of a Gray Squirrel . • . 48

VIII. OUR MOUSE, JiM • • • • • 56

IX. The Rabit (Common Hare) • • • . 6I

X. The Chicken - • . . . . 69

XI. IDENTIFICATION OF BIRDS • • • • 86

XII. THE RobIN • • • • • • • • 9 - 9

XIII. THE RED-HEAdED WOODPECKER • • 99

XIV. The Common CRow • • ‘ • • 109

XV. THE SCREech OWL • • • • • • II3

XVI. The English Sparrow . . . . . I20

XVII. Caterpillars • • • • • • 122 
XVIII. The Cabbage Butterfly • • • 129 XIX. The Milkweed Caterpillar . . . . I3I

\section{PART II. PLANT LIFE}

I. IDENTIFICATION OF FlOWERS . . . $\quad$ I4I

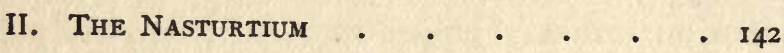

III. THE MORNING-GLORY . . . . $\quad$ I45

IV. The Common Blue Violet . . . 152

V. THE WILd ROSE . . . . . . 160

VI. TREE BUDS $. \quad . \quad . \quad . \quad . \quad . \quad 164$

VII. Autumn Leaves AND Buds . • . 167

VIII. A NUT GAME • • • • • • 176

IX. The APPLE • • . . . . . 177

X. The Austrian Pine. . . . . . 181 


\section{INTRODUCTION}

THE problem of working out suitable nature study lessons for primary grades involves numerous difficulties, which can best be solved by enthusiastic teachers working with the children. It is only thus that the broad general requirements of elementary science instruction can be adapted to the immature minds of little children.

In a general way it is not difficult to point out the requirements of this study, such as a growing interest in plants, animals, and weather conditions, and a closer habit of observation.

But a selection of the common objects upon which to focus the observations of children and the manner of directing their attention to these objects call out the best skill of experienced teachers.

One of the prepossessions which an adult teacher must get rid of in dealing with children in the midst of nature is the idea of system and classification in science. There should be no haste to reach the wise conclusions of the scientists. Children are more easily and properly absorbed in the objects and their surroundings, and there will be plenty of time later 
to hunt out the deeper truths. At the same time, however, children should gain a positive enrichment of knowledge and observation and should give expression to a definite fund of ideas and experience. In other words, the lessons should be fruitful in ideas and in the power to express them.

It is quite evident that a teacher in nature study must know how to live happily and companionably with children among the birds, flowers, insects, and trees. Merely to know how to enjoy an excursion with children is a great thing. In addition to this, one must learn to concentrate the children's thoughts along given lines, for a mere chasing after chance birds and butterflies will not answer. Having awakened the attention and interest of children in certain lines, it is necessary to lead on to more definite observations, and, sooner or later, to get from the children a clear statement of facts.

The teacher's questions and suggestions are designed to throw the children constantly upon their own power to observe, to experiment, to find out. Self-activity and thoughtfulness may be stimulated at every turn, and the foundation may be laid for an alert and self-reliant mind.

It is natural for children in these early years to observe, but the teacher should lead them to observe 
more closely, to inquire more definitely, and to be inquisitive about many important things which they would never think of if left to themselves.

While no two teachers in the same or in different neighborhoods would select just the same series of topics for primary grades, there is still great advantage in trying to pick out those objects which seem to be best suited to younger children and to give them a full treatment. Again, while the treatment of any given topic, as the red squirrel, would not be the same with any two teachers, it is still helpful to young teachers to see how an experienced primary teacher has handled one of these topics. A study of such lessons by younger teachers need not lead to any slavish imitation of models, but it may give an insight into the spirit and method of those who have gained success by experience and labor.

CHARLES A. MCMURRY.

WINTER PARK, FLORIDA,

January 6, 1905 . 



\section{PART I}

ANIMAL LIFE 


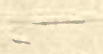

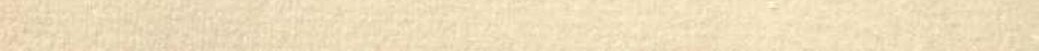




\section{NATURE STUDY LESSONS FOR PRIMARY GRADES}

\section{I \\ THE SHEPHERD DOG}

How many have seen a dog driving sheep? How did it drive them? (Trotted along behind them; if one lagged or went out of the way, the dog barked at it, or, if necessary, even snapped at it.) What do we call a dog that cares for sheep?

Pupils' aim: we shall see how shepherd dogs are fitted for their work of caring for sheep.

Some of you have shepherd dogs. Do they know much? How do you know? (Children relate what they know of this variety of dogs, the teacher telling stories from her own experience or such as she has read, illustrating their sagacity.)

When I was a little girl my father owned a shepherd dog, named Prince. We were all very fond of him. Our home was a long, long way from any neighbor, and in the daytime our sheep grazed on a 
4 NATURE STUDY LESSONS FOR PRIMARY GRADES

great pasture which was as large as this whole town. This was a queer pasture, you will think, when I tell you that there was no fence at all around it; and when we spoke of it we called it a prairie. Every morning Prince would help my father drive the sheep to this prairie. A place was found where the grass was good, and here the sheep would spend the day. One of their number wore a bell, and through the day we could hear the distant tinkle of the bell. If for any length of time we failed to hear it, some one went with Prince to the prairie to see what was the matter.

At night my father would call Prince and say, "Prince, bring up the sheep;" and away he would trot, alone, the very instant he was told to go. He gathered his flock together and drove them home. If any sheep was hurt or sick so it could not go, Prince, after trying to get it along, would leave it and drive home the others. He knew just how fast the sheep could go without becoming tired out, and no matter how many rabbits ran across his path, he never left the sheep to chase the rabbits, though he enjoyed nothing better when by himself. On reaching home, had a sheep been left behind, Prince would go to my father, look up into his face, bark, and start 
toward the prairie. We always knew from this that something was wrong, so my father would follow Prince and get the poor sheep home.

Our cattle were kept in a fenced pasture. One Sunday, on returning from church, we saw that some strange cattle had broken into this pasture and were grazing with our own. The gate of the pasture was opened and Prince told to "drive them out." $\mathrm{He}$ knew our own cattle well, and we all watched him as he went into the herd, picked out one by one the strange cattle, and drove them to the gate.

How do you think Prince could tell which cattle were not our own? (He had sharp eyes.) Have the shepherd dogs that you know sharp eyes? Why do you think so? Of what color are their eyes? Do all the dogs which you know have eyes of this color? Do the little puppies have brown eyes? Are the shepherd dog's eyes larger or smaller than your own? Of the same shape? Are they in the same part of the face as your own? Tell what you have learned about the shepherd dog's eyes.

But when Prince started out for the sheep, was it his eyes that told him where they were? (No, he could not see them.) How did he know where they were? (He might have heard the bell.) Could he 
hear well, do you think? Do your dogs hear well? (Children relate their experiences.) What does your dog do first when you call him? (Pricks up his ears.) Why? (So that he may catch all of the sound that he can.) Can you prick up your ears? (Our ears stand out so that we can catch the sound easily without moving them.) Where does the sound which the dog catches go? (Through the openings in the side of his head.) Did you ever look into these openings? What is to hinder flies, bugs, dust, etc., from going far into them? (Shepherd dogs' ears droop over these openings, and hair covers them largely.) How is it with your ears? What keeps insects out? Where on the dog's head do you find his ears? Are they higher up or lower down than our own? How many ears has he? Why does he need two?

Tell now all you can about a shepherd dog's ears.

But Prince sometimes could neither see nor hear the sheep, yet he started off in the right direction. How did he know where to go? He might have remembered. But if he had not remembered, quite likely he could have found them. Have you ever seen a dog that was lost from his master? What did he do? (Put his nose down close to the ground.) Why? (To scent the tracks of his master.) Can 
your shepherd dog smell well? What about the nose would make you think that he can smell well? (Yes, it is long, and pointed, and has large holes.) We call these holes nostrils.

Now, tell how a shepherd dog might find the sheep when he could neither see nor hear them.

Prince had to go for the sheep in rainy as well as in pleasant weather. $\mathrm{He}$ had no rubber coat or umbrella. How did he keep off the rain? (He had a good hair coat.) Why do you call it a good coat? (Shepherd dogs have thick hair all over the body.) What did he do with his coat in pleasant weather? Of what use was it to him then? (Kept him warm.) Did he wear such a coat in summer? Why? (To help keep bugs, flies, etc., from biting him.) Is not the winter coat too thick for summer? What is done about it? How do you know? (We do not like to handle the dog or have him in the house in the spring and summer when he is shedding his coat.) Is the hair next the body like that on the outside? Do you think this is well for the dog? Is a shepherd dog's hair the same length all over his body? Why shorter on the legs? Why on the face? Are there any bare places on his face? Do the flies ever bother him here? How does he get them off? 
(Shakes his head or brushes them off with his paw. Sometimes he sleeps with his paw over the end of his nose.)

No matter how fast Prince ran, his coat never looked wet with sweat. Did you ever think of it that your dogs do not sweat as do horses, or as you do? How do you think Prince showed that he was very warm? (He hung out his tongue; something that looked like water ran off from it.) Do you suppose that this cooled him off? Put your fingers into your mouth, then hold them up in the air a minute. What happens? (They get cold.) What happens when the wind blows on the dog's wet tongue? (It cools him.)

What is the color of the coat of a shepherd dog? Prince's coat was black, with a white collar, a white star in his forehead, and white toes.

You may tell, now, all you can about a shepherd dog's coat.

The road over which Prince went was a rough one; quite stony, too, in one place. Why did not his feet become sore? Notice whether the bottoms of his feet touch the ground as do yours when you walk. [Have a shepherd $\operatorname{dog}$ in the class if possible; if not, another dog will do.] What part 
touches the ground? (Only his toes and the ball of his foot.) On how many toes does he walk? Look at the dog's foot. Picture one of the front feet, also one of the hind feet. Has the dog a toe answering to your thumb? Point to it. One answering to your big toe? Point to it. Where are his heels? Feel of them. Some child, quite likely, may have on low shoes. Call attention to the great tendon of Achilles which lifts the heel. Where do we find this in the dog's hind legs? Where is his heel? Look at these toes on which the dog walks. Feel of the part that touches the ground. (It is almost as tough as leather. Each toe and the ball of the foot has a cushion with a very thick cover.) Do you think that the stones hurt Prince? Does the dog make much noise in running? Why not? Listen as he runs over the floor. What do you hear? Now you may tell all you can about a shepherd dog's feet.

When Prince came home at night we used to pet him. In what way, do you think? Do you think he liked to be petted? How would he show that he liked it? What was he telling us?

In what other way do you think we showed that we cared for Prince? (Gave him a good dinner.) 
What do dogs like best to eat? How do they eat the meat? (Swallow large pieces without chewing. They sometimes hold the meat down with their front feet, or hands, while they pull off pieces of it.) What part that we never eat do they eat? (Bones.)

[Bring a gentle dog to the class and examine its teeth.] What are these long, sharp teeth for? Have you such teeth? Show me that you have. Are they longer or shorter than those of the dog? What are these smaller front teeth of the dog for? How many? Have you such teeth? Where? With what teeth does the dog chew the bones? Are they good teeth for that? What do dogs do with bones left from a meal? (Bury them.) Why? Where? How do they make the hole in which to bury them? Which claws do they use? What kind of claws does a dog need to dig with? (Strong claws.) Why? (So they will not break.) What shape must they be? Look at the shepherd dog's claws and find if they are strong and slightly curved. How does he cover the hole? Notice carefully. How get the bones from the hole?

We also set a pan of water where Prince could get it. How did he drink it? Watch your dogs drink water and tell just how they do it. Do 
dogs drink much water? How much at a time? Sometimes they suffer because their masters forget that they need water.

Not long after Prince had had his dinner he went to bed. What kind of bed does a dog like? Did you ever watch a dog lie down in his bed? What does it do? Children report later, if not ready now.

Did you ever hear a dog talk? Prince was a good talker, after his fashion, and we could understand what he meant, usually. In what ways do you think he talked? ((a) He growled when he did not like what he saw or heard. (b) He barked hard and long when he wished to drive animals away. (c) $\mathrm{He}$ barked short, happy barks when he was glad to see us. (d) He whined when not allowed to follow us into the house. (e) He snarled at any one who tried to get his food away from him, or at a tramp. (f) He howled when left at home alone. $(g) \mathrm{He}$ yelped when he was hurt.)

He had a way of talking, also, without making a sound. How was that? (By moving his tail.) What did his tail tell? (When he wagged his tail, it told us that he was pleased, or that he thought we were going to give him something that he liked. Dogs wag their tails just before they "speak." When he 
was frightened, or ashamed, he carried his tail down between his legs.)

The children might review the whole subject of shepherd dogs by going with Prince after the sheep.

Do you think shepherd dogs are useful? What have we found that they can do? What other helpful things have you seen them do?

Other species of dogs familiar to the children may be studied by comparison with the above, thus:-

What other kind of dogs do you know? One has a rat-terrier. How many have seen one? (Probably all.) How does a rat-terrier help us? (Catches rats.) How is it that he can catch rats better than a shepherd dog can? (a) He is much smaller. How does this help him? (He can go under piles of rubbish and into holes where a shepherd dog could not go.) (b) He is quicker in his movements. How does this help? (A rat runs fast. A dog must be very quick to catch it.) (c) His cutting and biting teeth are smaller and sharper than those of a shepherd dog. (d) His hair is straight, short, and stiff, and lies down close to his body, so he can more easily get into holes than the shepherd dog with his long, thick, curly hair. 
How true a friend is a dog? Tell what you know about this.

What do you think of him as a playfellow? Tell what he plays. Tell how little puppies play.

Tell other things that you like about a dog.

\section{II}

\section{THE CAT}

We have talked of the usefulness of the dog. What other animal that lives about the house is useful ? Of what use is the cat? Let us see how it is fitted for catching mice.

How does the cat know that a mouse is about? (Quite likely it hears it gnawing.) How does the cat show that it is listening? [If the children have not noticed how the cat shows attention, have a cat in the class. A child scratches, not very loud, on the wall. Notice the effect on the cat.] How does it hold its ears? Its head? How does it show that it knows from what direction the sound comes? What does it do if the scratching continues? Notice its eyes. How do they look? Is the pupil - the black part in the center-large or small? Could the mouse, without seeing kitty, tell that she is coming 
over the floor? Why not? How can she move so softly? Notice closely the cushions on her feet. Which moves the more quietly, the dog or the cat? Why cannot the dog move over the floor as quietly as the cat? (His claws touch the floor.) When a cat has found the hole of a mouse, and knows the mouse is within, what does it do? How long do you think it will wait? Does it stand or sit? What have you noticed about its tail while it is watching for the mouse? How does it catch the mouse? We saw no claws while looking at kitty's feet. Where were they? What reason can you think for kitty having claws that she can pull in when she chooses to do so? (She can walk so softly a mouse cannot hear her; her claws are kept from being broken or dulled.) What have you that corresponds to the cat's claws? What care do you have to give your nails? Why cut them? Do kitty's nails grow? What does she do to keep them from becoming too long? (Scratches on trees or other wood.) How does the shape of her claws fit her for catching and holding a mouse?

Often in hunting mice cats have to go into holes. They have a way of telling whether or not the hole is too small for their bodies; what is it? (The 
whiskers extend outward a long way. Any hole which is so large that the whiskers do not touch its sides is wide enough for the body of the cat to pass through.) What are the whiskers sometimes called? (Feelers.) Why? Notice what the cat does even when you touch her whiskers lightly. How do these feelers help her when she is moving about in the dark? Some people think cats can see well in the dark, but we are told, by people who should know, that this is not so, hence it is well that cats have feelers and hear well, if they wish to hunt in the night. The cat's eyes are queer. Notice pussy's eyes when the sun is shining brightly in her face. What are the shape and size of the pupil? Why does so little of it show? (The circular curtain - which gives color to the eyehas been drawn nearly together so as to keep the sun from hurting the eye.) What is the color of this curtain? Is it of the same color in all cats? Notice the shape of the pupil when it is nearly dark. Why is the pupil so large? (The curtain has opened wide, to let in much light, so that the cat can see well.)

What besides mice does the cat sometimes catch? How can it get birds? One cat catches many birds 
in a season, so that people who care very much for birds will not have a cat about.

What else do cats catch? (Young rabbits.) Where do they find these? Watch a cat as she hunts in a field and tell what you notice about her.

What besides little animals does a cat find to eat out of doors? (Catnip and fresh grass.) How does she eat them? With what teeth does she nip them? (The small front teeth.) [Show a good picture of a cat's open mouth; there is one in "Cats and Dogs," by James Johonnot. Have the pupils notice, also, the teeth of their cats at home, if they have gentle cats.] Of what use are the long, strong teeth in the fore part of each jaw?

We have been speaking of the food which the cat gets for itself. Do the pussies you love have to get all their food by hunting? What do you feed them? How do they drink milk? Watch your cat to see how. (It is very difficult to see just how the cat laps milk, she takes it up so fast.) What else does she lap?

What besides milk do you feed the cat? How does she eat meat? Does she crush bones as the dog sometimes does? Notice the back teeth to see if they are fitted for crushing. How does 
she get meat from bones? (She laps it off.) How can she do this? (Her tongue is rough. It has little hooks on it, which point backward.) What does the cat do if you take her meat from her? What does she often do to the plate after eating all the food from it? Look at the plate she has lapped. How could she get it so clean? (Her rough tongue makes a good dishcloth.) How does the cat ask for food?

After pussy has had a good dinner, what does she do? (Sleeps.) Where does she like to sleep in the winter? (By the stove or in the sun.) How does she lie as she sleeps? Where is her head? Her tail? In the summer time where does she sleep? (Often in the grass in the shade of a tree.) Watch her when she wakens. What does she do?

Now that pussy is well fed and wide awake she may like to play. What have you seen her play? How did she play?

Does your cat like to stay in the house all of the time? How does she ask to be let out? Watch her as she walks off; how does she walk? When the weather is cold, how is she kept warm? Examine this coat. Put your fingers into it. All the air in the coat is warm; that helps to keep the cat warm. 
Is her coat of the same thickness in the summer? How do you know part of it comes out? Stroke pussy's fur in the right way; how does she like it? How do you know? How does she like to have it stroked the other way? Why is it well for pussy that her hair extends backward and downward? sheds the rain.) When kitty gets in out of the rain, what does she do? Why shake herself? What is the color of her good coat? How does the cat keep it clean? Tell how she washes the top of her head. What other parts does she wash with her paws?

Sometimes when the cat is out walking or hunting she gets frightened. At what, do you think? What does she do when a strange dog comes toward her? How does she climb a tree? What does the dog do? (Barks and puts his paws up against the tree as if he were going to climb it.) Why doesn't he climb the tree? How long does the cat stay up the tree? After the dog is gone, how does the cat get down? Watch her and tell. Why does she have a harder time getting down than up? Remember the position and shape of her claws. If the cat cannot find a tree to climb and cannot get away from the dog, how does she defend herself? When the cat gets 
back home, how does she ask to be let in? How does she show that she is glad to see you?

We have been talking about how kitty spends the day. What do you do with her at night? What kind of bed do you give her? Where?

You have not told about the cunning kittens. Why do we call them cunning? How does the mother feed them? How keep them clean? Tell how they play with their mother. How do they play with one another? How does the mother carry them?

Have a reproduction of all the children have learned about the cat.

\section{III}

\section{THE HORSE}

We have been learning many things about some of our animal friends. What ones? (The dog and the cat.) Can you think of any other animal that does very much for us? (The horse.) How many of you have horses at home? Tell me some of the things your horses do for you. Tell of some of the heavy loads you have seen, them haul. Could men draw such loads? How is it, then, 
that horses can pull so much?

(They are very strong, much stronger than men.) Do they often appear unwilling to do such heavy work? Do they work very long at a time? (Nearly all day, often.) After you have worked a little while you become tired and stop to rest. Do horses ever need to rest? Can they stop whenever they wish? Why not? Do masters think about their horses becoming tired? (Kind masters do.) The children have probably noticed horses with heavy loads being stopped on the road that they might rest. Is there any danger of putting on too heavy loads? Children have no doubt noticed that sometimes horses have more than they can well draw. How do the horses show that the load is too heavy? (By trying very hard to pull it.) Must they draw the too heavy load? (Yes, unless the master is kind enough to take some of it off.) Why does not the horse refuse to draw such a load? His master would whip him and make him do it. What do you think of treating horses in that way? Sometimes horses refuse to try hard to pull a load. Have you ever seen horses refusing to go? What do we call this? (Balking.) Have you noticed the size of the horses that are kept for heavy work? (They are very large and have strong, heavy legs.) What 
other things do these horses do for us? (Draw plows, harrows, reapers, etc.)

What else do horses do for us besides drawing heavy loads? (They take us riding in carriages, carts, and sleighs.) Why do you not drive cows? (They go too slowly.) In some places they work cows. Here is a picture of some oxen taking a load of children to a picnic. Where oxen are used, it is usually to draw heavy loads, not to take people out for the pleasure of a ride. When you are out riding, do you like to go fast or slowly? Do the horses that people drive fast look just like those they use for heavy work? (No, they have lighter bodies and their legs are more slender.) Why are such horses better for driving? Compare movements of the heavy Newfoundland dog with those of the light rat-terrier or greyhound to show that heavy animals are slower in their movements than the lighter ones. Does the horse seem to enjoy going out for a drive? How does he show that he enjoys it? How do horses know which way you wish them to turn? (If the driver wishes the horse to turn to the right, he pulls the right line. If he wishes him to turn to the left, he pulls the left line. When he wishes him to stop he pulls both lines and says "Whoa.") How can the lines tell the horse 
where and when to turn? (The lines are fastened to a bit in the horse's mouth.) Of what are bits made? How do they look? (Children show by a drawing.) Afterward, if any child has never seen a bit, the teacher shows one, explaining how and where the lines are fastened. In what part of the mouth is the bit held? [Children observe that the horse has front teeth and back teeth, and that between the two groups of teeth there is quite a long vacant place. Into this the bit fits. Children show place for bit by diagram on the board. The teacher has a bridle in the class.] What is this I have here? (A bridle.) What are these pieces of leather for? (To hold the bit in place.) Notice what is fastened to the sides of the bridle. (Two square or oblong leather pieces.) Why are they there? (To keep the horse from seeing many things. $\mathrm{He}$ might become frightened at some of these things.) Without these blinders, as these pieces are called, could the horse see things at either side without turning his head? How is that? His eyes are so placed in his head that he can see to the front and to the sides also. The eyes are far apart and are large. Would you like to have to look straight ahead all of the time? Can you see things to the right and left without turning your 
head ? (Not well.) Why not? Do you suppose the horse likes to have his view of the sides of the road cut off? Some masters have their bridles made without blinders. What do you think of that?

But horses with blinders, and horses wholly blind, sometimes become frightened. What could frighten a blind horse? (Sounds of cannon, firecrackers, barking of dogs, etc.) Has the horse good ears? Tell me how you know. On what part of his head does he carry his ears? What shape are they? Did you ever see him move his ears? How? When? Why? Do the horse's ears ever lie down? When? You may draw the horse's head, showing where his eyes and ears are. Where shall we draw the ears? (Standing up side by side from the top of his head.) Look closely at their shape.

We all know how to guide the horse; let us see how he pulls a buggy or sleigh. Is it in the same way that you pull your hand sleds and express wagons? (No, we pull them with our hands. The horse has no hands.) No, the horse's arms are his fore legs, and it cannot take hold of the buggy with them, but I have seen children draw sleds very much as your horse draws your sleigh or buggy. How is the horse fastened to the sleigh? [Children explain 
from observation.] The purpose is to show how the pulling is mostly done by the breast and shoulders. In the same way children sometimes, in drawing a loaded hand sled, have a rope fastened to the two sides of the round in front; this they put over their shoulders so that the weight rests there. Any who have never drawn sleds in this way are shown how. Do horses get tired traveling all day when the load is light? (Yes, if driven fast.) How do they show that they are tired? (Go slowly.) Then what does the driver often do? (Whip them to make them go faster.) And what do the horses do? (Go faster. They have to do as the driver wishes, and if he does not care for his team they will often have a hard time.) How do horses show that they have been driven too rapidly? (They are covered with sweat, even in cold weather, and they breathe fast, the breath coming from their great nostrils in clouds.) What care should they receive at the end of their journey when they have been so overdriven? (They should be wiped dry with a cloth, then covered with a blanket. They should not be given much water to drink at first, although they are thirsty, but should wait until they are cooled off.)

How else besides to draw heavy loads and take 
you out riding are horses used? (People often ride on their backs.) Did you ever ride horseback? Did the horse walk when you were on its back? In what other ways do riding horses sometimes move along? (Sometimes trot, or pace, or gallop.) How do the horses' feet move in trotting? Children observe that the right fore foot and the left hind foot move forward together. How do the horse's feet move in pacing? Children see that the two right feet are raised at the same time, then the two left feet. How do horses gallop? Children notice that the fore feet are lifted together, then the hind feet. Can you tell whether a horse is walking, trotting, pacing, or galloping, without seeing it at all? (Yes, sometimes, by hearing the sound of its feet as they come down on the ground.) What is it about the foot that makes this noise? (Its hard hoof or its shoe.) What is this hoof? (The horse's toe nail.) Of what shape is the horse's hoof? Does it go all the way around the toe? Picture its shape on the board. Where is the hoof the broadest? Where narrowest? If this hoof is the horse's nail, on what does a horse stand? (On its toe nail.) What kind of toe nails must these be that they may hold up the heavy body of the horse and may stand being brought 
against the hard ground or pavement ?

(They must be strong and hard.) Should you not think that they would wear off? Look at horses' hoofs. (The lower part of some hoofs looks ragged.) Do you ever lose part of your nails? (Yes, mamma cuts the ends off.) Then do they stay short? (No, they grow out again.) So the horse's hoofs or nails wear off and grow out again as your nails do. It is better for the horse to have his nails trimmed, as you have yours, but sometimes they are allowed to grow rough like those we have noticed.

How do horses keep from slipping on ice? (They wear iron or steel shoes usually.) [Teacher has a shoe in the class.] How are these shoes put on to the horse? [Visit a blacksmith shop if possible.] Does it hurt the horse to have the shoes nailed to his hoof? Does it hurt you to have your finger nails cut? Neither does it hurt the horse to have nails driven into his hoofs. How many nails are put in? How are they driven through the shoes? [Children notice the holes for nails, in the shoe.] What are these three sharp piecestwo at the heel and one at the toe - extending downward? (Calks.) What are they for? (The horse is so heavy that as it comes down with its 
weight on its shoes, these pieces cut deeply into the ice, keeping the horse from slipping.) When a horse is shod with such sharp shoes, we say he is rough shod. Look at the tracks of horses on the ice. What do you see? In the summer or during time of good roads, some horses wear smooth shoes, like this - showing one. Feel of it. We said before that the horse was rough shod; we might now say that he is how shod? (Smooth shod.)

What else does a horse use his feet for besides walking, running, etc.? (He strikes with them to knock off flies. He kicks his enemies.) Children give examples. How else does he protect himself? (He bites.)

We have found that horses can be driven in winter without danger of falling. But do they not get very cold without overcoats? (They have a hair coat.) We will call the skin an under coat. This is thick and warm. These coats keep the horse warm enough when traveling. What shall be done for horses when standing waiting for us? (They should be covered with blankets.) What protection do they need in cold weather, when not working or traveling? (A good warm stable, with a clean straw bed to lie on.) 
Do the horses wear the same coat winter and summer? (In the spring they shed their old coat and keep only the new one that began to grow out the summer before. So they are not dressed as warm in summer as in winter.) Children relate what they know of the horse shedding his coat. There is other hair on the horse which protects him in summer. What is that? (His tail.) How does the horse use his tail in the summer? (To brush the flies off.) Where else is the hair long on the horse? (On the neck.) What do we call the long hair there? (A mane.) How would you like the looks of a horse without a mane?

We have found that the horse does a great deal for us. What makes him strong and able to work? (Good food.) What does the horse like to get in the summer time? (Green grass, and he likes to be out in the pasture and get it for himself.) How does he get the grass into his mouth? (By the aid of his thick lips.) And how does he bite it off? Has he or has he not teeth in his upper jaw? Children observe that he has. After he has the grass bitten off, what does he do? (Chews it.) Notice how his jaws move in chewing. Up and down or sidewise? 
What else do horses eat besides grass and hay? (Straw, fodder, oats, wheat, corn, and carrots.) How does the horse eat salt? How drink water? What other animals drink in the same way? What ones drink differently? Does the horse drink much? How much? How often should he be watered? (It is best to have water in the pasture so the horse can get it whenever he wishes.) If the horse is being driven, water him often.

How does the horse let us know when he wants to be fed or watered? (He whinnies or neighs.) Tell of some other times when he whinnies. (If his mate is taken from the field or stable, he whinnies for it. That is the way, too, the mother calls her little colt. Horses sometimes whinny for their masters, too.)

The teacher should insist on the children making the observations for themselves.

Frequent reproductions by topics should be required. Thus: "Tell how the horses are kept from slipping on the ice." "How are they protected from the cold ?" 


\section{IV}

\section{THE COW}

To what animal did the old woman (in the story of "The Old Woman and Her Pig") go last for hèlp? (To the cow.) What did she want the cow to do for her? (Give her some milk.) But before the cow would give her any milk, she must do something for the cow. What was that? (Give her some hay.) How much did she give her? (An armful.) Is an armful of hay enough to last a cow all day? How many of my armfuls do you think it would take? Why does a cow need so much to eat? (She is large.) As large as a shepherd dog? (Much larger. A shepherd dog could walk right under a good-sized cow.) Where do the farmers get this hay that the cow likes? Do the cows ever get it from the fields, themselves? When? Did you ever watch a cow eating grass? What did she do first? (Put her head down to the ground.) Could you do that? (Yes, if I could stand as a cow stands.) Do you think so? How does the cow stand? On what? Its toes, as the dog does? (No, it stands on the nails of its

1 "Classic Stories for the Little Ones." Public-School Publishing Co., Bloomington, III. 
third and fourth fingers and toes.) What do we call these nails of the cow? (Hoofs.) Where are the nails on our fingers? (On the back of the ends of our fingers.) Where are the nails of the cow? (Her nails or hoofs go all the way around.) Feel of them. (They are very hard and thick.) Does she need such hoofs? Why? Notice the shape. (They look like one hoof cut in two.) Because they look this way we say the cow has a cloven hoof. Cloven means cut in two, but we know that she has two nails or hoofs on each foot. Now you know how the cow stands. How is it? Does the cow find it hard to stand? Can she reach the grass on the ground with ease? How does she gather the grass? (She reaches out with her tongue and draws a wisp into her mouth, and nips it off with her teeth.) What kind of tongue has she? (A long, limber, rough one.) Why does it need to be so long? Why limber? Why rough? What else does she use in gathering the grass? (Her thick, broad lips.) [These answers should be the result of the child's careful observations.] How does she bite off the grass? (With her front teeth.) Have you noticed anything strange about these front teeth? (The cow has no front teeth in her upper jaw.) How then can she bite off the grass? (The 
upper front jaw is very hard, almost as hard as a bone.) Does she eat rapidly? How long does she chew on a mouthful of grass? Does she keep on eating all day at this rate? (No; after a while she lies down, or stands and rests.) Did you ever notice how a cow lies down? Does she lie down as the dog does? What does she do first? Then what? If you watch her mouth while she is lying down or standing, if at rest, what will you find her doing? (Chewing her cud.) What is this cud, and where does it come from? I will tell you. Where does your food go after you swallow it? (Into the stomach.) Now, a cow has a very large stomach. The grass which she bites off she chews but a little, if any. She swallows it, and it goes into a room in this big stomach, where it soaks for a while. Watch a cow's throat a little while after she lies down, and tell what you see. (Something going up her throat toward her mouth.) This is a little of the soaked grass going up to be well chewed. We now call it a cud. What becomes of this cud? (After it is chewed up fine, the cow swallows it and it goes into another part of this big stomach.) Then what? (Another cud goes up to be chewed in the same way, and so on.) Do 
the cow's jaws move as yours do when chewing? How do yours move? (The upper jaw does not move. The lower jaw moves chiefly up and down.) Do the cow's jaws move in that way? (Her upper jaw does not move, but her lower jaw moves from one side to the other.) What does this sidewise motion of the lower teeth on the upper teeth do for the grass? (Grinds it up. It is her mill in motion.) Which teeth do the grinding? (The back teeth.) Let us see if they are good grinders. [Have jaw of cow if possible.] (They are broad, flat, and hard.) Is it a good thing that the cow can pack away her food, and chew it when at rest? (Yes. She can gather grass in the cool of the day, then lie down in the shade when the sun is hot, and eat it. She does not have to stand as much as she otherwise would, but can rest while eating.)

In the winter time, what does the cow eat instead of grass? (Hay, straw, and fodder.) She eats these as she does the grass, i.e. chews them slightly, swallows, then re-chews as a cud. What besides grass, hay, and straw does the cow like to eat? (Corn.) How does she get hold of the ears of corn? How does she eat corn? What becomes of the cob? What else does the cow like? (Oats, meal, and bran.) 
How does she eat them? What is bran? Can you think of anything else we feed the cow? (Carrots, turnips, beets.) How does she eat them? Anything else? (Salt.) Do we salt the cow often? How does she eat it?

Can you think of something else she would want? (Water.) How often should a cow be watered? Does she lap up the water as the dog does? How, then, does she drink?

[All these answers made by the children should be the result of their own observations.]

Is there anything we can do for the cow in the summer, besides feeding her well? (Give her a pasture in which there are trees or a shed to protect her from the hot sun.) And in the winter, what? (Give her good shelter from the cold and snow, and a good straw bed at night.) But has she not a hair coat to keep off the cold and snow? (This coat helps, but it is not thick enough to keep her warm in bad weather.) Is it as thick as the horse's coat? Are the hairs of the same length as his? Are they as fine? Does she wear the same coat in summer and winter, or has she a lighter coat in the summer? How do you know? Is her coat the same color as that of the horse? We do not often see the cow's 
coat wet from sweating. When she gets warm, she opens her mouth, lolls out her tongue, and pants, much as the dog does. In the winter you can see the steam coming from her great nostrils. Have you noticed these nostrils?

Where is the hair longest on the cow? (On end of tail.) What use does she make of this long brush? But she cannot keep the flies off her neck and shoulders, even with so long a brush. (She drives them off by tossing her head about.) How does she keep them off her feet and fore legs? (Stamps her feet.) Children speak of the trouble of milking cows in summer on account of flies.

Can you think of any other way she has of driving away things that bother her? Does she bark or bite, as the dog does? (She has horns to hook with.) [Have a horn in the class if possible.] Can she hurt with such horns? (Yes, the outside is very hard, and they are strong and sharp-pointed.) From what part of the head do they grow? Is that a good place for them? Why do you think so? How does she use them? When? (Not so often to defend herself as to protect her calf. She is very fond of it.) Did you ever see her drive away dogs? How else does she show that she is fond of her calf? (She cries for 
it if it is taken away. She licks it with her tongue. That is the only way she has of kissing it. She stands still for it to get its dinner.) Do you think the little calf pretty? What do you like about its looks? (It has pretty eyes for one thing; so has its mother.)

We have found many things that we can do for the cow, now we shall see what she does for us. What does she give us night and morning? How do we get the milk? Which gives the more, the cow kindly cared for, or the cow poorly housed and fed? For what do we use milk? Do we get cream from the cow? Do you see it when she is being milked? (No, we only see the milk.) Where do we get the cream? (It rises on the milk.) What is made from cream? (Butter.) How is butter made? [If possible, watch the process.] What is made from cream and milk? (Cheese and cottage cheese.) What else is cream used for? (Ice cream, etc.) 


\section{V}

\section{THE SHEEP}

\section{(By Comparison With the Cow)}

What other animals, besides cows and calves and horses, have you seen grazing in pastures? (Sheep.) Have all seen sheep? [If any are unfamiliar with them, a visit should be made to one; or, better, to a flock. Perhaps some child may have a pet lamb, which, like Mary's in the poem, might follow her "to school one day." This would afford an excellent opportunity for close study.]

Watch the sheep as it eats grass. What does it do? How does it bite off the grass? (With its front teeth.) Look at these front teeth. [The children might do this at home and report the following day. They discover that the sheep has no teeth in the front part of its upper jaw.] What other animal have you found lacking teeth here? (The cow.)

See how long the sheep chews the grass before swallowing. What are these sheep over here doing? (Lying down and chewing their cuds.) What will these sheep that are eating so rapidly now do by and by? What other animal eats grass in the same way? (The cow.) From what you know of the cow's cud, 
tell how you think the sheep gets its cud? [Children review process of rumination in the cow. If this study is taken up in the winter time, the children observe the sheep eating hay instead of grass.]

Which eats the grass off the shorter, the cow or the sheep? Why can the sheep do this?

Does the sheep eat corn in the same way that a cow eats it? [Children name any differences that they may have observed.] (A sheep nibbles off the kernels.) Watch it and see how it does this. What else does it eat? Does it eat carrots, turnips, and beets, as a cow eats them? What difference? Does it hold the food down with its foot, as the dog sometimes does, when eating its food? How do sheep eat salt? How drink water?

Notice how lightly the sheep step about. Let us look at their little feet. What do you find? (They, like the cow, walk on their toe nails - two on each foot.)

Did you ever think how much the cow and the sheep are alike? They surely must be cousins. Name those points in which they are alike.

(a) Both have cloven hoofs (walk on toe nails).

(b) Both lack teeth in front part of the upper jaw.

(c) Both chew the cud. 
Are they unlike in any ways? Look at the two as they graze side by side. How can you tell them apart? (The cow is much larger than the sheep. The sheep could run under the cow. The sheep is nearer the size of the shepherd dog.)

If both were of the same size, could you tell them apart by their looks? (The sheep has a wool coat, the cow a hair coat.) Is there any other difference in these coats, except that one is wool and the other hair? (The sheep's coat is usually white - occasionally brown; the cow's coat may be white, red, black, or spotted.) Is there not still another difference between the sheep's coat and that of the cow?. (The sheep's wool coat is much thicker than the cow's hair coat.) Let us look closely at this wool coat. Have wool in the class. Each child may pick some to pieces and see if it is at all like the cow's hair coat. (It is hair, only the hairs are much finer than those of the cow, and they are wavy and seem to be fastened together, so that it is hard to pull them apart.) Stretch one of these fine hairs. What about its length now? (It is much longer than it looks to be when on the sheep.) Does the wool lie down on the sheep's body in the same way that the hair lies down on the cow's body? 
You have said that the sheep and cow are unlike in size, and wear different kinds of coats. If the sheep were the same size as the cow and wore the same kind of a coat, could you tell them apart? (Not many sheep have horns.) Do all cows have horns? (Many have none.) Could you tell them apart by the looks of their horns? Look at the sheep with horns and the cow with horns and see. (The cow's horns are round, quite smooth, and pointed. They usually start out from the head in opposite directions, then curve inward and forward so it can hook with them.) [Children show by drawing at the board.] The sheep's horns grow backward and downward, often forming a curl. They are not round, and are rough. [Children draw a sheep's head to show how its horns look.] Can you think why it is well that the sheep's horns do not stand out in front of its head? (Sheep crowd close together in the fold at night, or when frightened, and sharp-pointed horns such as the cow has would be apt to injure other sheep.)

How can sheep keep away their enemies with such horns, or no horns at all, as in most cases? [Children relate any experience of their own, or such as they have heard, of the terrible blow given by 
a sheep with its head, butting. The large horned sheep are usually willing to do the fighting for a flock. They are no cowards. The teacher might relate instances showing the bravery of the rams in defending a flock.] Have you ever noticed a mother sheep when a dog came near her lamb? What did she do to show her anger? (Stamped her foot.) And if the dog came nearer, what did she do? She can fight to save her baby from harm, even though she has no horns. You may tell again of some difference between the horns of the sheep and the cow.

In how many points have we found the sheep different in looks from the cow?

If the sheep were like the cow in size, wore the same kind of coat, and had the same kind of horns, could you still tell them apart? Look closely at the animals and see. (The end of a cow's nose is wide and bare. Its nostrils are far apart. The sheep's nose is more pointed. There is hair on the end of its nose, and its nostrils are quite close together.)

Let us name the difference in looks between the sheep and the cow. (a) The sheep is smaller than the cow. (b) It wears a wool coat, while the cow wears a hair coat. (c) The sheep's horns are differ- 
ent from those of the cow. [Children explain.] (d) Their noses are different. [Children explain.]

But I might be able to tell a sheep from a cow without looking at one. How? (By its cry. A sheep says, "Baa." A cow says, "Moo." We call a sheep's cry a bleat, and the cow's a low.) When do we hear the sheep bleating a great deal? (In the spring when the lambs are little.) And how do the lambs answer their mothers' calls? The sheep bleat also when they are hungry or thirsty. So we can tell sheep and cows apart both by seeing and by hearing them. The scent of the sheep is also peculiar.

We found that the cow does a great deal for us. Is the sheep also our good friend? What does it do for us? (Its wool is made into blankets for our beds, warm shawls, cloaks, coats, etc.) [Children show garments made of wool.] How do we get it from the sheep? (Men cut it off with great sheep shears.) How often? But is it not very dirty after being worn without change for a whole year? [Children tell about sheep washing, which occurs a few days before the shearing. If none have seen the process, the teacher explains and shows pictures.] Then, when their wool becomes dry, what is done? [Children who have seen sheep sheared explain how the coat is 
taken off, and how packed away. The teacher shows good pictures to those who have never seen this done. Show sheep shears, explaining how they are worked.] An explanation of the making of wool into cloth is given later.

Which does the most for us, the sheep, the cow, the horse, the cat, or the shepherd dog? Which one do you like best for a pet?

\section{VI}

\section{THE FOX SQUIRREL}

\section{(A Winter StUdy)}

It is supposed that this study will be carried on with classes of children who have often seen this squirrel, and are to some extent acquainted with its habits. A live squirrel, if possible, will be brought into the class whenever facts in regard to structure need proof.

The following questions may be asked for the purpose of finding out how much the children already know about the animal: Where have you seen fox squirrels? How could you tell them from other squirrels? Their color is orange (or red) and gray. What have you seen them doing? Did you ever visit 
at one of their homes? Where was it? How did you reach it? How was it furnished?

We will see if we cannot become better acquainted with this lively little fellow.

Have you seen any this winter? Was it on a very cold or a mild day? At what time of day? What was it doing? Watch closely and see if you can find out. Can you ever tell that a squirrel has been out, even though no one has seen it? How? What kind of tracks does it leave in the snow? Notice them so carefully that you can draw them on the board. If you were to follow these tracks, what might you find? (The squirrel's home.) We will not disturb him, but sometime when the house is empty we will climb up and peep in and see if he has a comfortable home. The children, quite likely, may find the nest in a hollow of a tree. It is lined with leaves and moss, perhaps. How many rooms? (Only one-a bedroom.) Does one squirrel live here alone? There is a whole family of them, quite likely - father, mother, and two or three children. Perhaps you can find out how they pack themselves away in this snug home. Did the squirrels dig out this hole in the tree? Why do you think they did not? Why should they 
choose such a place as this? Did you ever see squirrels out house hunting? Did you ever see them fitting up their home? How did they carry the leaves and moss? How many of the family worked? At what time of year was it? Do they have a door to their house? How, then, do they keep out the wind and the snow? Is there a furnace or a stove in this house? How, then, can they keep warm? (They wear very warm fur coats.) Without a squirrel, the study of this covering can be made from a dried pelt. Is there more than one coat? Notice the inner coat. It is very soft and compact, a dark drab next to the skin, resembling cotton batting. What does this coat do for the squirrel? Notice the outer coat. This coat is coarser and not so compact. Do the hairs stand straight out from the body, or do they lie down? What is the use of this coat? Which coat gives the color to the animal? Notice these long hairs in which the dark and light alternate. Which color is at the tip of the hairs?

These are not the squirrel's only protection from the cold. What besides? (He carries with him a beautiful fur cloak - his tail or brush - which he wraps about him when he lies down to sleep.) Call 
attention to the richness of coloring in this cloak. The upper part in this specimen before me is a beautiful combination of black and orange, the orange tipping every hair - while the under part (which is the upper part most of the time) is a light orange.

We have found that the squirrels are very comfortable even in cold weather. But are a good home and warm clothes all that are necessary to keep them alive? (They need food.) What do squirrels eat? How can they get these after the fruit and corn are gathered and the nuts which remain on the ground in the woods are covered with snow? (They stored up food in a pantry in another hole in a tree, not far from their sleeping room.) Did you ever see them gather nuts for the winter? How did they carry them to their pantry? How many worked at this? Did you ever come across their store of nuts? Did you examine it? How good a selection had they made? Were there any wormy ones among them? How do you think they discover that a nut is not sound?

How do the squirrels spend most of the time in the winter? Why do you think so? When they waken and are hungry, how do they get their 
meals? (Scamper off to the pantry.) Do they eat at the pantry, or bring the nuts back to the bedroom? How do they hold the nuts when eating? How get at the meat? (Show shells from which the squirrels have taken the meats.) What kind of teeth must they have to gnaw into the shell in this way? Do they chew their food? With what teeth? [If possible, examine these teeth. The skull of the squirrel would be of much service here.] What is the movement of the jaw? Is it well for the squirrel's teeth that he does not sleep all winter? What would be the harm if he were to do so? (His teeth keep growing. He needs to keep them worn off at the tip that they may not become too long.)

We know a little about the winter life of this pretty squirrel. Its summer life is even more interesting. Let us find out all that we can about that, next term. See how early in the spring it begins its work and play. We will find out, if we can, what its summer work is, and what games it plays. 


\section{VII}

THE FIRST THREE MONTHS IN THE LIFE OF A GRAY SQUIRREL (SPENT IN a SCHoolroom)

Our school children had the rare opportunity in the spring of ' 97 of observing three gray squirrels, from the time of their birth.

We had had the mother of these babies for about six weeks, when, on Monday morning, March I5, our janitor found in the cage five little squirrels. Two died shortly after birth. The little squirrels were perfectly naked, not a hair on the whole body. The bodies of the two largest were two inches long, the tails one and one fourth inches long, and the legs three fourths of an inch long. They were very dark red, with the heads darker than the body. The ears were no larger than radish or flax seeds. Their eyes were as large as sweet peas, but were closed tightly. Their toe nails were black, with a white tip, and were well developed.

The mother purred to them harshly. The babies mewed - a single mew at a time; their voices sounded like those of kittens. We saw two of them getting their dinner the second morning. Their 
front feet moved in a happy way while nursing. We made them a nest of cotton in a box when they first came. Their mother tore up much paper and added to this nest.

When they were a week old their bodies had become plumper, and they had begun to bleach out. We took one of the little ones from the cage. It squealed like a little pig, - such a big voice for such a tiny creature! The mother, Fanny, was very tame. We patted her and handled her considerably when the squirrels were a week old, without any disposition on her part to bite.

When a week and a half old, the little ones began to squeak like mice whenever things did not go to suit them in their home. Their little ears began to stand out. The mother, when she feared some one was going to hurt one of her babies, planted her front feet firmly upon its body.

When three weeks old, the lids to the eyes had become plainly differentiated. The body had changed in color to a dark gray, and gray hairs began to show. They were thickest on the head. The head looked very large in proportion to the rest of the body. The ears were now standing out stiffly. Ten days previous to this the squirrels had 
been taken to the home of one of our teachers to spend the vacation. Fanny was frightened at being moved, and when her cage was set down in the new quarters, and the box containing her little ones was put in, she grabbed up one little one at a time and lapped it. She seemed to be examining them to see if any harm had come to them. At the close of the vacation they were three times as large, at least, as at the beginning of it.

When three and a half weeks old the little squirrels had become very active. Hair covered all of the body excepting the belly and the inner side of the legs. These parts were still perfectly bare. The tail had grown to be quite large. The order in which the hair appeared was this - on head, on body, on outer part of thigh, on outer part of leg. The mother's call sounded like a buzz saw.

When four and a half weeks old the eyelids were much swollen and looked to be about ready to open. The head of the squirrels still seemed out of all proportion to the size of their bodies. For several days previous to this, rusty hairs had been noticeable on the squirrels' heads, mixed with the gray, and now a rusty line showed low down on each side of their bodies. While the outside of the 
mother's ear is white, theirs was gray. Their tails were now becoming very hairy. They still continued to do nothing but sleep, eat, and squirm. They were never quiet. For two days previous to this time Fanny had seemed very uneasy. She jumped out of the nest and called her young, but they made no move to follow her. On this day she had many times taken up one of the babies in her mouth and lapped and handled it, especially the latter. We put much cotton into the cage so they might not suffer were she to take them from the box. When lifting one, she usually grasped it by a leg, or the skin on the back of its body - far back. When five weeks old the under part of the body and inner part of the leg were thickly covered with white hairs.

When five and a half weeks old we found each little squirrel with one eye partly open. With the two larger squirrels it was the left eye, with the smaller one it was the right eye. The smallest squirrel was of a much lighter gray than the other two, and had no rusty hairs in its coat.

On the morning following that of the above record we looked with expectancy for wide-open eyes, but only the little gray had an eye open, its right eye, 
as before, but this was hardly as wide open as on the previous day. Fanny, about this time, began to lie flat on her back to suckle her little ones. For several days previous to this she had been burying her food in the nest. On this day she took a piece of cotton from her bed, and with her mouth and front paws gave it a good shaking, then put it back into the nest.

On the day following the above record, one of the large squirrels opened neither eye all day. The other large one had both eyes open, not wide, but about halfway. The little one had its right eye open, but no farther than on the previous day. The squirrel with both eyes open drew itself up so as to peep over the top of the box. Fanny, seeing it, drew it back into the nest. By this time we were in the habit of handling the little ones and taking them out of the cage. Neither Fanny nor the little ones objected.

When the little squirrels were six weeks old, for the first time all three had both eyes open. They did not move about much on this great day, slept as usual, but were more restless. Fanny now began sunning herself, stretching out flat on the bottom of the cage. 
Two days later than the above record the little squirrels took up cracked nuts in their paws and nibbled them. The smallest squirrel at this time was the most active. On the evening of this day one of the little squirrels kept getting out of the box. Fanny was displeased. Every time it got out she would run after it and, grasping it by the hind leg, lift it into the box. At one time the little fellow ran about on the floor of the cage, in a very animated manner.

Five days later the little ones had begun to walk and run about the cage a great deal, and on this day, for the first time, they climbed up the sides of the wire cage. When walking or running they. still seemed unsteady on their feet, and when holding up a nut in the paws, as they did on rare occasions, their hind legs wabbled. On this day and once previously, one little fellow worked at its mother's mouth - seemed to be biting her teeth. We examined its teeth and found them just through. We think it was using its mother's teeth as a baby, when teething, uses an ivory ring. The mother was very patient and seemed to regard the operation as perfectly proper. The little teeth were very tiny and very white. The little squirrels had sharp 
nails. We could hardly get them off our clothing when they had been running over us.

One day after the above record all three little squirrels lay down on the bottom of the cage together to sleep.

When eight weeks old their tails were beautiful and they curled them gracefully over their backs. They had by this time become very nimble. They would take away Fanny's nuts when she was nibbling them. Fanny stored away in the box large quantities of nuts, never putting two in the same spot. She covered them by scratching anything over them that happened to be handy, even though it were one of the little squirrels.

Two days later one squirrel would lie on its back, kick up its legs, and grab another squirrel, when a skirmish would follow. They continued to steal the nuts from Fanny's mouth. They were now beginning to eat nuts, kernels of corn, and clover. One lay down and gnawed a kernel of corn as a dog gnaws a bone.

When nine and a half weeks old the little ones teased Fanny when eating so much that she hung by her toes from the side of the cage near the top, to crack nuts. The tails of the babies were 
now longer than their bodies. The little ones were becoming hearty eaters, their favorite food being hickory nuts. On this day I wore a snowball. Fanny came to the side of the cage and nibbled at the snowball. When I took it off and gave it to her, she ate more than half of it.

One day later than the above Fanny and her babies quarreled. She was tired of having them boss her about, and refused to submit.

When ten and a half weeks old Fanny still washed her babies, lapping them with her tongue. She still suckled them, though a few times she had resisted their demands for food. They now looked to be almost as large as the mother. The smallest one was a downright wicked tease. It made a practice of skipping up behind one of the others and biting it, stealing the food of the others, biting them when they wished to eat, and the like. Finally we had to take the little hector out of the cage and give him a cage to himself.

About a week after this one of the squirrels which remained in the cage died. We know no cause for its death. We took the other little squirrel from the mother, as she had been taking its choice morsels of food from it. We kept it out only three days, as 
it grieved greatly for its mother. The evening after we put it back it had a hard spasm. Fearing that the room was too warm and sunny, we sent all to the basement in another building. Here they were given much freedom and throve well. This was near the end of the term. The children had watched closely and noted with greatest interest all the changes here recorded, and they loved the little squirrels and Fanny very much. They related to the teacher in their nature study class what they had observed. If any difference of opinion existed, it was settled by closer observation.

\section{VIII}

\section{OUR MOUSE, JIM}

The following are some observations made, in the schoolroom, of our mouse, Jim.

Jim was not a handsome mouse. He was gray, with the under parts somewhat lighter. Our janitor caught him for us in a trap - one of the kind that preserves the specimen alive and unmutilated. Before he arrived we had made ready for him a cage. It was made of woven wire, and was about a foot square. It had a wooden bottom, 
which the mouse never saw fit to gnaw through. There was a wire handle at the top, and a wire door in one side, near the bottom. This door was of such a size that the top of a glass fruit jar exactly fitted into it. The cost of the cage was fifty cents. A tinner made it for us.

As often as the cage needed cleaning, Jim was tempted by some dainty to go into a two-quart jar whose mouth had been put into the door of the cage. Once in there, the top of the jar was put on lightly, and the cage was cleaned. Jim, almost without fail, gave himself a thorough cleaning while in this jar. Standing on his hind paws, he lapped his little pink hands, and then proceeded, much as a cat does, to clean very carefully all parts of his body, his hands returning to his mouth frequently.

In the meantime the cage had been washed out thoroughly and dried, and a double piece of paper a foot wide but several inches longer was put into the cage, so that one side folded over, forming a roof for a retiring room. Jim had asked for this room in this way: At first we cut the paper a foot square. Jim would invariably push up one side of the paper and go under it when he wished 
to sleep or meditate. By lengthening the paper we saved him this trouble. He had not ceased to be wary, although he knew us well, for he always cut out a little window in this private office of his, and slept with his head in such a position that he could look out of this window.

How happy he was to get back into his clean cage! He would run up one side, throw his head far back, and turn a somersault, landing on his feet at the bottom of the cage. This was his favorite pastime. His movements were so rapid, when he was fairly started, that it was impossible to tell how he moved.

The children at school were glad to furnish food to the little fellow for the pleasure of seeing him eat. His mouth was hid from sight. If a grain of field corn were given him, he picked it up in his front paws, standing on his hind legs, exactly as does a squirrel when eating a nut. He first pulled off with his teeth the thin husk on the outside of the grain, dropped it, and, beginning at the crown, ate downward toward the heart of the kernel for some distance; then he turned it and ate toward the heart from the opposite side, until one part dropped. The remaining part he ate from the outside inward, nib- 
bling little bites, or sometimes taking larger bites and chewing them. When the one part was eaten, he scurried around, hunting the other portion, which he ate in the same way. If he had an abundance of corn, he would eat the crown out of several kernels, instead of eating an entire one. When a kernel of rice popcorn was given him, instead of beginning at the crown to nibble (the crown is very hard), he began at the softer base.

We expected him to go into raptures over his first bit of cheese, this being considered a mouse's great luxury, but he disappointed us. He nibbled a little from it occasionally, but in a half-hearted way.

He was very fond of cake. One could almost hear him smack his jaws in satisfaction when he got hold of a piece. He would hold it up in his paws, if not too heavy, and eat it in much the same way that he ate the corn. If the piece were too large, he put his head down to it, using his paws in turning it. His hands seemed as necessary to him, for feeding himself, as do ours. We never saw him eat anything without bringing them into use to hold the food in a good position for nibbling. We watered Jim in a little glass salt cellar. He 
cared for water at least once a day. Sometimes he would drink oftener. When the water was put into the cage he would run to it, put his two front feet on the side of the dish, and lap up rapidly from the center. Occasionally we gave him milk. This he would sometimes lap from the center, at other times from the edge of the dish only.

His hand was very delicate. There were four slender fingers on a level, and a thumb higher up, as in our own hand. The foot had but four toes, the use of the toes being less varied than that of the fingers.

While we do not doubt that his prominent nose served a good purpose, we were not able to demonstrate to our satisfaction that he has the keen scent accorded him by some.

His little black eyes seemed to see in every direction at once, and his thin papery ears caught the slightest sound. His whole attitude was one of alertness. A cat that could surprise one such little fellow must be very quick-witted as well as quickmotioned.

So far as we could discover, his tail was a useless appendage - not even ornamental, we should say; but Jim seemed very proud of it. He washed it 
with great care, and laid it out in a graceful curve, when resting. We think he would look quite inartistic, however, without this three-inch measure, and were it covered with hair, forming a beautiful brush like that of the squirrel, probably not a mouse would be making history to-day.

\section{IX}

\section{THE RABBIT (COMMON HARE)}

The purpose of the first recitation is to find out what the children know about the subject.

Did you see some little tracks in the snow this morning as you came to school? What made them? (Dogs or cats.) Did you see any others smaller than these? What had made them? (Rabbits.) Show me on the board just how these tracks looked. If the children cannot do this, ask them to notice closely and draw a picture of them on paper and bring to class next day. When do you think the rabbit made them? (At night, perhaps.) Why was he running about at night? (To get food.) Why not get his food in the daytime? ( $\mathrm{He}$ is afraid some enemy will see him and catch him.) Then the rabbit has enemies? Name some of the 
enemies that you know. (Men, dogs, cats, snakes, hawks, owls.) To-morrow we shall see how these tracks of Bunny's help some of his enemies to catch him.

At the next recitation the teacher brings in a tame rabbit, introducing it as gray Bunny's cousin, which hops just as gray Bunny does, and has ears and eyes much like his, except the color of the eyes. The teacher takes the pictures called for the day before. Explanations are made of how the rabbit makes three tracks instead of four. The two front feet strike together, and the two hind feet come up on the sides, striking a little in front of the two front feet. Which feet move first, the fore or the hind feet? Which pair of legs help him the more in hopping? (Hind legs.) How are they fitted for helping him so much? (They are long and strong.) What about the front legs? (They are shorter and weaker.) How is it that the rabbit can get about so quietly? I will hold him so that you may see if you can find out. (The soles of his feet are cushioned and covered with hair.) Why does Bunny need to get about so quietly? (So his enemies will not hear him.) But we have found out that when he hops he leaves what? (Tracks.) And we 
said yesterday that some of his enemies were helped by these tracks to catch him. What enemies? (Men. They see the tracks and follow them.) What other enemies are guided by the tracks? (Dogs.) How do the tracks help them? Did you ever see dogs hunting rabbits? What did they do? (Kept noses down to ground.) What doing? (Smelling the tracks - "getting the scent.") Do they need to see the tracks? (No.) What will Bunny do to get away from the dogs? How will he know that they are coming? (See them.) Look at his eyes; where are they? (On sides of head.) How does that help? (He can see all about without turning his head.) What does he turn? (His eyes, so that when he is running he can see the dogs back of him.) What else tells Bunny that the dogs are coming? (His ears.) Are they good ears? Give a low bark in the next room, Earl. What did Bunny do? (Stuck up his ears.) Why? (To catch the sounds.) What else do you notice about his ears? (He can turn them in any direction.) How will this help him? (Even if he cannot see the dog, he can tell from what direction he is coming without turning his head.)

Now that Bunny sees or hears the dog, what will 
he do? (Run.) Can he go fast? How do you know? (Have seen him.) (Those long, strong hind legs help him.) - How does he hold his ears when running? (Down and back.) Why? ( (a) So that they will be out of his way when running under fences and brush. (b) So that the air pressing against them will not hinder him. (c) So that he can hear his pursuers.)

In what other way than by running can he get away from the dogs? ( ( a ) He may glide into a hole or hollow log. (b) Turn suddenly when the dog gets up to him. The dog cannot turn so quickly, and not expecting this change in affairs, loses some time, the rabbit improving it in getting away. (c) Crouch down on a $\log$ or in the bushes. His color being very similar to that of the log or bushes, the dog will sometimes give up the search after sniffing about for a time within a short distance of him.)

If Bunny escapes from the dogs, he goes where? (To his home.) Where is it? (Near some log, under bushes, at foot of tree, or in the weeds.) What kind of a house? (A hollow in the grass or weeds.) Is there no roof to his house? (No.) Sometimes there is. What kind of a roof do you think it is? There is sometimes such a roof on your 
house, over the other roof. (Snow.) How did Bunny get such a roof? (Remained in his house, or form, during a snowstorm and let the snow cover him.) Does snow make a good roof for him? Why do you have warm covers on your bed at night? (To keep us warm.) How does it keep you warm? Is not the cold air all about your bed? (The covers keep it out and keep the warmth in.) What does the snow do for Bunny? (Keeps cold air out and the warmth within.) How can he breathe in there? Did you ever breathe on the ice covering the window, some cold morning? What did your warm breath do to the ice? (Melted it.) What does Bunny's breath do to the snow? (Bunny's breath melts the snow a little, so he can get fresh air.) How long will Bunny stay in his snow-covered home? (Till he gets hungry.)

Why does the hunter want to kill Bunny? ( (a) For food. (b) For his fur. (c) For fun. [What do you think of this?] (d) Because he eats the vegetables in summer. (e) He girdles the farmer's trees in winter.)

Does it not seem that with so many enemies there would be no rabbits left? This would be true were there not so many young rabbits every year, enough to take the place of those killed. 
We have learned something about Bunny's enemies. Why do gardeners and fruit raisers often kill rabbits? (Because they eat their vegetables in the summer and gnaw their fruit trees in the winter.) Why do they gnaw the fruit trees in the winter? (Food is scarce then and they like the bark of trees.) Do they gnaw young or old trees? (Young trees, because they have tender bark.) What kind of teeth must the rabbit have to gnaw this bark?

(Sharp teeth.) Must all the teeth be sharp? (The front ones, at least, must be so.) What else should be true of the front teeth that they may nibble off the bark? (They should be long.) Why? (So his gums will not be injured by the wood of the tree.) Something else must be true of his teeth, also. Think of the kind of food he is getting and how he is getting it. (They must be strong.) Let us open Bunny's mouth - for tame Bunny has teeth like those of wild Bunny and see if his front teeth are sharp, long, and strong. What do you see? (Two long, sharp, strong teeth in each jaw.) Here are some of Bunny's teeth (taken from a skull) and here are some knives. Let us see if the front and back part of the teeth are equally hard. (The front is the harder.) As he nibbles the hard bark, what will become of the softer 
back of the tooth? (It will wear off faster than the front part.) What will that do for the tooth? (Sharpen it.) Will not the teeth finally be worn down to the gum? (They would, did they not keep growing out from the gum.) What would happen to Bunny did he not wear off his teeth? (They would keep on growing and become great tusks.) (The teacher might cite examples of deformity caused by one tooth being broken off.) Do you blame Bunny, then, for nibbling something hard?

Look at Bunny's mouth. Do you see anything about it that helps him in nibbling the trees? (The upper lip is cleft.) How does this help? (The lip is out of his way when nibbling, and so does not get hurt by rubbing against the tree.)

After Bunny nibbles off the food, what does he do with it before swallowing it? (Chews it.) With his sharp front teeth? (No, with chewing teeth such as we have.) Let us see if Bunny has such teeth. (He has.)

Now Bunny has finished his breakfast or supper off the bark of the tree. Has he harmed the tree much? (Killed it if he has gnawed all the way around.) How is that? (The roads through which the sap passes from roots to leaves, and from the 
leaves back to the roots, are spoiled.) [This presupposes a study of the tree.] And so the fruit grower would like Bunny to stay away from his orchard, and when the weather is warm and there is plenty of clover and vegetables, Bunny is willing to do so.

Has he ever been to your garden? Did you see him? How did you know, then, that he had been there? The parsley, lettuce, beets, etc., told the story. Does he like flowers, too? Yes, and he has good taste - a great liking for carnations and other pinks. Now this tame rabbit eats as does the wild one, so we will ask him to show how the gray rabbit eats, since we cannot catch gray Bunny eating. We will feed him parsley and carrot and apple. (Children try many different kinds of food.)

What have we found Bunny using his front teeth for? (Gnawing.) Now watch him. What does he do with the parsley? (Bites off a mouthful, then chews it.) And with the tender leaves of the beet? (The same.) And what does he do with the apple? (Gnaws off a little at a time.) Then he uses his front teeth for what? His back teeth for what?

Tell me some interesting things you have learned about the gray rabbit. What else would you like to know? A study of the young will follow later. 


\section{$\mathrm{X}$ \\ THE CHICKEN}

In Grimm's story of "The Street Musicians," when they had stopped in the wood for the night, where did the rooster settle down? (In the top of a high tree.) How did he get up so high? (He flew to one of the lower branches, from there to a higher one, and so on.) Why do you think so? (I have seen chickens fly up into trees, and that is the way they always did.) Why doesn't a chicken fly directly to the top of the tree from the ground? (Its wings are not strong enough to carry its heavy body so far without stopping to rest.) Does a chicken have much flying to do? When does it fly? (To and from its roost.) Where does it roost? Where did the rooster roost after his good supper in the robbers' hut? Have you seen chickens fly at other times than those just spoken of? (Sometimes, when they cannot get through a crack, they will fly over a fence.) How? [Children give their observations.] They usually fly to the top of the fence, light there, then fly down on the other side. Why do they make so much noise about it? (It is such hard work.) 
Do you know what is sometimes done to chickens to keep them from flying over fences?

(Their wing feathers on one wing are clipped.) How does this hinder them from flying so high? (They cannot balance themselves.) How does a chicken fly? beating its wings against the air.) You can raise your heavy body a little way from the ground by pushing down on two posts driven into the ground. A bird has no posts to push against, but it can press against the air. That is always handy, too. [By the use of a light fan, fanning downward and outward rapidly, the children become conscious that there is a resistance of the air.]

[We do not wish to go deeply into this subject. Perhaps it would be wise not to touch upon it at all, but usually the interested children bring up the question and force some explanation of how birds fly.] The motions of the wings made by the chicken in flying - are they slow or rapid? In raising its wing why does not the air above push the bird back? The chicken does not raise its wing straight up, it cuts through the air with the front of the wing, - so (showing with the fan).

You have seen the wing of a chicken on the dinner table and it looks much smaller than when 
on the chicken. Why is that? (It has the feathers off.) [If possible, the teacher should have a gentle hen in the class, also the wing of a dressed chicken, and a wing with feathers upon it. Compare in size the two wings.] Is this hen going to fly now? How do you know she is not? (Her wings are not spread.) The teacher extends and contracts gently the wing of the hen a few times. Does that make you think of anything you sometimes see? (A fan.) When does the chicken close its fans? When it does not wish to use them in flying? Why does it not keep them stretched out all of the time? (They would be in its way.) When? Can you show with your arms how the hen closes her wings, or arms? What does she do when she wishes to fly? [Children relate their observations.] Show how, starting with your arms in the position of the closed wings. This will require close observation. [Call attention to the position of the thumb or forefinger in the dressed wing.] Do your arms now look like the chicken's spread wing? (No, the skin that holds the two parts of the hen's arm, or wing, together is wanting in our arm.) What, then, can you do with your arms that the hen cannot do with hers? (Stretch them out straight.) Picture on the board 
John's arm stretched out. Beside it picture the dressed wing stretched out. What is this wing mostly made of? (Skin and bones.) Can you think of any reason why it may be well that there is no more meat on it? (The meat would make the wing heavy. She would tire holding out a heavy wing in flying.)

But the hen has besides the skin, bones, and muscles, what? (Feathers.) Do these help or hinder her flying? (She spreads out these feathers and strikes against much more air than the naked wing could press against. She could not rise at all with the naked wing.) Let us look at one of these large wing feathers and see if we think it is the kind the chicken needs for flying. Lift it. (It is so light that I cannot feel its weight.) Does the chicken need light feathers? Why? Is this feather straight? (No, it curves downward a little.) Is this well? The feathers hold the air under better than they would if they were flat. [They will notice the difference in pressure of a concave and a flat fan.] How many of these long feathers? Does it need so many? Pull a feather from this wing which I have here. [The feather comes only after hard pulling.] Is it well that the feathers are fastened so tightly? 
Why? We will look closely at these feathers. This middle part is called the shaft. Each side is called a web. Is the web of the same width on both sides? (Notice how the feathers are arranged on the wing.) The narrow web of one covers the wide web of its neighbor. Only one side needs to be long, and the chicken wishes to have as light wings as possible, as we have said before. Can you think of any reason for having the narrow web over the wide one? Examine the wing. Would it do just as well to have the wide web over the narrow?

Notice one little part of the web. That is called a barb. Separate carefully these barbs. (They cling closely together.) After you have separated them, smooth them down. What do you notice? (They cling as before.) Hold the feather up to the light as you slowly separate these barbs. What do you see? (Each barb has little teeth on both sides. These teeth fit into those of the barbs next to them.) Is that well for the chicken? (Yes, if the feathers let the air through, it would leave nothing to press against and the chicken could not rise.) What do you notice above these long feathers? Of what use are these feathers? Above these, what? Can you think how else the chicken is helped by having 
74 NATURE STUDY LESSONS FOR PRIMARY GRADES

feathers that shut out the air? (Its body is kept warmer.) How are the little chickens helped by such feathers? (The wings keep the cold air from them at night, as the hen covers the chickens with her wings.)

Are all the barbs on the hen's feathers hooked together? [Examine one of the small feathers.] On which part of the feather are the barbs hooked together? (On the part that is on the outside of the chicken. The part that is covered is softer-more like down.) How are the small feathers arranged on the hen? (They all point backward from the head, and grow one over another like the shingles on a house, only closer together. The barbed part is on the outside.) Is this well for the hen? Why? (It makes a very thick cover, keeping out the cold, and also sheds the rain quite well, the rain running off the end of one feather on to the next, and so on until it drops to the ground.) Have all the feathers some barbs? Where do you find feathers without barbs? Notice how a hen stands in the rain. (With her tail drooping, as if to let the rain have a chance to run off by the way of her tail feathers.) In what other way is the chicken helped to keep dry in rainy weather? Have you noticed what a hen sometimes does during 
a rain? (She oils her feathers so that they will shed the rain.) Will oil shed water? How do you know? [Have oiled paper in the class. Pour water on it and see what happens.] Where does the chicken get the oil? (From a little sac just above the tail.) [Show on dressed chicken.] Where does the oil come out? How does the hen get it out? (With her bill.) How can she reach away around there with her bill? (Her neck is long and limber, and she can twist it around easily.) How does she get the oil out? (Presses down on the sac with her bill, and it comes out as does the juice when you press on an orange in which you have made a hole.) How does she carry the oil to the feathers? With her bill? How put it on the feathers? (She passes each feather which she wishes to oil between her two mandibles.) Her bill is the finest comb the hen has.

But her hair combing is no queerer than her bath. Did you ever see a hen bathing? No? Did you ever see a hen in an ash pile or in a pile of dust fluttering about? Just what did she do? [Children find out if they cannot tell.] This is her bath. Does she seem to enjoy it? What does she do when she is through her dust bath? Change her clothes? No, but she shakes out the dust and preens her feathers. 
76 NATURE STUDY LESSONS FOR PRIMARY GRADES

(Smooths her old dress.) How? Does the hen never change her dress? Have you not seen many feathers lying about the henhouse? Did something pull them out? Do they usually come out easily? How does this happen, then? (Little by little she is changing her dress. An old feather falls out and a new one grows in to take its place. Sometimes a hen loses the whole of her tail at one time.) When does this changing of dress happen? (Late in the summer.) Is this a good time? Why? How do the little new feathers look when they first come in? What do we call them? (Pinfeathers.) Examine these carefully if they can be found when this is studied. Why does the hen need to change her dress at all? (The feathers wear out and become much mussed.) Is there any order in shedding her coat? [When one wing feather comes out, its mate on the opposite side is said to fall out also. Watch and see if this is so.] Are the dresses of the little chickens like their mother's? (No, the chickens are covered with down.) How is the down different from feathers? (Down has no shaft and web.) Before going farther the children tell what they have learned about chickens flying, about their wings, and about their feathers. 
Have any of the other animals that we have studied feather coats? What kind of coats did they have? (The shepherd dog, cow, cat, and horse have hair coats, the sheep a wool coat.)

Where did we find the rooster in our story roosting at first? Where later? Where do the chickens that you know roost? Why should they leave the ground? (Sometimes the ground is cold and damp. When on a high roost the chickens are not so apt to be disturbed or killed by rats, skunks, dogs, etc.) How do they hold on to the roost? [If no one in the class can tell, the children may be given time to find out for themselves by watching the chickens at home.] (Its three front toes curve around the roost in front-this way-(showing with the fingers) while its hind toe reaches around behind and steadies it.) But when the hen is asleep will she not stop holding on and fall off? Notice a hen as she raises her foot in walking slowly. How do the toes look? They curl up very much as if holding to a perch. When do her toes' spread out? (Only when her feet come down on the flat ground. At other times her feet are in a position to hold on to a perch. And the weight of her body only tightens her hold.) When the hens 
are on the perch do they stand up all the time or do they sit? Find out. Do they close their eyes? At what time of day do chickens go to their high beds? (About as soon as the sun goes down.) Do we hear from them at all during the night? (The old rooster crows occasionally.) How early in the morning do chickens get up? (In the summer time, as soon as it begins to be light. In the winter, they, like ourselves, hate to get up into the cold, so they stay on their beds sometimes until after sunrise.) Can you think of any other reason why they do not get up (or get down, rather) earlier in the winter? They have not so much work to do. There are no bugs or worms or vegetables to which they may help themselves. What do they eat in the winter time? Where do they get it? Did you ever notice how the hen eats the corn? [The teacher can feed the one she has at school.] What did she do? (Picked up the kernels very fast with her bill.) What kind of a bill has she? (It is hard.) Is that well? Why? (It is strong.) Why does she need a strong bill? (It is pointed.) Why is this a good thing? The upper mandible is curved. Is it better so? Why? Notice how the forefinger is curved in picking up 
a pin from the floor. Notice the shape of the lower mandible. What do you think of that? The bill has sharp edges. Is this well? (Yes, the chicken can cut off pieces of leaves, grass, etc., very easily with such sharp knives. She can cut them off as fast as she can swallow them.) What other animals did we find swallowing food very rapidly? (Cow and sheep.) But was this the last we heard of this poorly chewed food? (No, the cows and sheep re-chew their grass, hay, etc., as a cud.) Have you ever seen chickens chewing a cud? (They do not.)

Let us see if we can find why a chicken does not chew its food. With what do we chew our food? (Teeth.) What kind of teeth has the chicken? Very carefully open the hen's mouth and the children will see that she has no teeth. Then why does the chicken not chew its food? What becomes of the corn that it takes into its mouth? (It swallows it.) How many have ever watched the dressing of a chicken? Did you see its crop? Feel right here on our hen. That is its crop that you feel. The food that it swallows goes first into that. I have here the crop of a chicken. We will open it and see what we find. [There is 
nothing repulsive about this to the children, as all have seen dressed chickens, and many have watched the process of preparing them for the table.] Now the corn, grass, etc., stay in the crop until they are very well soaked, then they pass on to the gizzard. Do you know the gizzard? It is the chicken's stomach. Here is one. Feel of it. It is very thick and tough. We will open it carefully. [Peel so as to leave the inner sac intact.] What kind of coat is this outer coat? (Strong and thick.) We will open the inner coat. What do you see? (The food ground fine, and some pebbles.) Take hold of this inner sac. (It is tough and elastic.) Where is the door through which the soaked corn comes into the stomach? When it gets inside of this mill it is tossed back and forth with the stones and becomes very fine, as you see. From this food the chicken's blood, flesh, fat, and feathers are made, and its muscles and bones are repaired.

Name other things that the chicken eats in the winter. And in the summer time what? Where do they find the bugs, spiders, etc.? How catch them? [Children watch chickens and see.] Where do the chickens find the worms? (In the ground.) How get them out? (With their sharp toes.) Did you 
ever see a chicken scratch for worms or seeds? How did it do the scratching? Then when it found something good to eat what did it do? (Picked it up quickly with its bill and swallowed it.) What happens when a hen with her little chickens finds something good? (She calls her little chickens with some quick clucks and lets them have what she has found. When they get over being hungry she feeds herself.) How can she see the little seeds and bugs! (She has bright eyes.) Where are they? Is this well for her? Why?

We have spoken of the hen's food, but not of her drink. What does she drink? How? (Puts her bill into the water and then raises her head.) Does her bill move when in the water? What is she doing? (Filling it.) Why does she raise it? (To let the water run down her throat.)

How do you think the rooster that belonged to the band traveled? (Walked.) As we said before, chickens fly but little. On what do they walk? (Their toes.) About what other animal that walks on his toes have we talked? (The shepherd dog.) Does the rooster walk as the shepherd dog does? (No, it walks on the toes of two feet, the dog on the toes of four feet.) On how many toes does the 
chicken step? (Examine tracks in snow or mud.) Does the hind toe help any in walking? Of what use is it? Are the front toes all of the same length? Which is the longest? Why is it well that the chicken has long toes? (If his toes were very short his body would more easily tip over. He could not grasp the perch well.) Are their long nails in the way when walking? Why not? Look at the base of the front toes. (A little web is there.) Why? What keeps their toes from being hurt by stones, rough dirt, stubble, etc.? (They are covered by tough, hard rings.) This long part from the toes up to the joint is the chicken's heel. Is the heel naked? (No, covered by plates of tough, hard skin.) Have you ever seen any chickens with feathers on the heel and toes? Notice how tiny are the little chicken's toes. Can they get about well?

Did you ever call the chickens to feed them? Did they hear you? Then what did they do? How can the chickens hear when we call? Have they ears? Did you ever see them? [Very likely the children may never have thought of a chicken's ears.] The teacher calls attention to the ears on the tame hen, or better, the children find them. Why is it well 
that her ears are so small? Why do the ears need to be thus protected?

It is said that the hen's scent is good, as well as her hearing. How can we find out if this is so? Where is this hen's nose? (The children will find its nostrils, quite likely.) Are they protected?

Now look at this hen and tell me what you like about her looks. (Her feathers are pretty.) What is it that you admire about her feathers? What else do you think is pretty about the hen? (She wears a pretty red comb on top of her head.) How do you like the looks of the little chicks? (They are cunning.) How are they dressed? (In fluffy down.) With their round bodies and heads, and tiny wings and bill, and bright little eyes, they make a beautiful sight.

Where did these little chicks come from? (From eggs.) How do you know? Tell what care the eggs must have that they may hatch. (Before the chickens are hatched, the mother hen must sit on the eggs three weeks, keeping them warm all the time, or they are kept warm in an incubator.) How does the hen get food and drink? (She leaves the nest just long enough to get food and water.) Would you know a sitting hen were you to meet one? How? When 
the little chicks are ready to leave the shell, who opens their shell door for them? (They do.) How? (Notice the little drill on the bill.) Do you see it on the bills of the older chickens? At what time of the year do these little chicks come into the world? (In warm weather, usually, in spring or summer.) Why not in cold weather? How do they get a living when young? How many little chicks has the mother often to scratch for? Does she complain about her hard work? (No, she likes it.) How does she call her little chicks when she finds a nice worm? Does she talk with them as she walks out? What does she say? And how do the little chicks answer her? (By a happy little " peep, peep.") But when one gets out of sight of its mother or gets into trouble? (Then it cries a loud, long, lonesome wail, until its mamma hears it and runs to it, or some person comes to help it. It is a good thing that a chicken can let us know when it is in trouble.)

What kind of sound does the mother make when she sees a hawk in the sky or a snake in the grass? What does this sound tell the little chickens to do? (To hide in the grass.) Does the mother hide, too? (No, she is ready to fight for her babies if there is need of it.) How can she fight? (With her bill, 
wings, and feet.) Did you ever see her fight an enemy? Tell about it. Teacher also relates instances.

How old are the little chickens when the feathers begin to grow? Where do you first notice these new feathers growing? How big are the little roosters when they begin to crow? How well do they crow? Tell how they look when trying to crow.

Review the life of the little chick from the time the hen goes on to the nest to begin her sitting, up to the time when the feathers begin to grow.

How else are eggs used besides for sitting ? Children tell of the many uses of eggs. How do we know that a hen has laid an egg? (She cackles.)

Various drawings are made from time to time. The old hen and a little chick are represented side by side, showing the difference in size.

Frequent reproductions are given by the children on topics assigned by the teacher, as: "Tell how the mother hen protects her babies;" "Tell how the hen cares for her feathers." 
86 NATURE STUDY LESSONS FOR PRIMARY GRADES

\section{XI}

\section{IDENTIFICATION OF BIRDS}

The employment of games in teaching the names of the birds in first grade makes the recitation very enjoyable, gives a chance for exercising the little bodies, and facilitates the learning of the names of the common birds. A few games only will be suggested; the resourceful teacher will think of many others.

\section{HUNTING BIRDS}

The colored pictures of birds with which the children are becoming acquainted may be placed about the room on the blackboard ledge. The children hunt birds. One is sent for a junco, another for a chickadee, etc. Only one trial is given any child. The children see who can find the most birds. The teacher must see to it that each child is called upon as many times as every other child.

\section{SIX LITTLE BIRDIES}

(In this game each child holds the small colored picture of the bird he represents.)

Six little birdies,

Very much alive; 
The wren flew south,

And then there were five.

Chorus. Little wren, little wren, Happy and gay,

Little wren, little wren,

Flew away.

Five little birdies

Wished there were more;

Bluebird flew south,

And then there were four.

Chorus. Bluebird, bluebird, etc.

Four little birdies

Sitting in a tree;

Robin flew south,

And then there were three.

Chorus. Robin, robin, etc.

Three little birdies

Wondered what they'd do ;

Blackbird flew south,

And then there were two.

Chorus. Blackbird, blackbird, etc. 
Two little birdies

Hadn't much fun ;

Kinglet flew south,

And then there was one.

Chorus. Kinglet, kinglet, etc.

One little nuthatch

Left all alone;

He went too,

And then there was none.

Chorus. Nuthatch, nuthatch, etc.

-Arranged by Ethel Patchin.

(Sing to the tune of "Five Little Chickadees.")

DiReCtions FOR Playing. - The teacher or one child sings the stanzas, the children joining in the chorus. As soon as the child representing the wren hears the wren's name sung, he flies from the ring. If he fails to respond, he is caught, and another becomes the wren.

The number playing this game need not be limited to six.

\section{THE BIRDS' PARTY}

Several little girls have pinned upon each a tiny bow of ribbon, indicating the bird which she represents; e.g. the robin has a bow of robin-red ribbon pinned upon the breast, the red-winged blackbird 
has a bow of scarlet ribbon pinned upon the shoulder, the bluebird has a bow of blue upon the back.

A number of boys, corresponding to the number of girls, are sent out of the room while the girls are receiving their names. On their return each is given a name corresponding to that given to one of the little girls. As they stand about the room the teacher nods to one, and he says, "I am Sir Robin looking for my mate." (As he speaks he flies about among the girls, looking for the one wearing the robin-red ribbon.) When he has found her he says - "Hasten with me (Jennie) lest we be late," and they fly to a corner of the room, where they are received by a host and hostess who welcome them and give them perches (chairs or seats upon a strip of carpet).

As soon as Sir Robin finds his mate, another starts, in like manner, looking for his mate, and so the game moves along rapidly.

When all have arrived at the party, the couples form into line, led by the host and hostess, and fly airily about the room; then at a signal from the teacher each little bird takes his mate home, bowing to her politely as he leaves her. 


\section{TEST EXERCISES}

Children who have observed closely quite a number of birds will enjoy occasionally test exercises like the following:-

(a) What birds that you know wear some robinred? (In Northern Illinois this list will quite likely contain the robin, the bluebird, the catbird, the orchard oriole, the red-breasted nuthatch.) The pupil who has the longest correct list is the winner in the contest.

Make a list of all of the birds which you know which wear white; black; yellow; blue; red; brown.

(b) What is the smallest bird you know? Name other little birds.

What is the largest bird you know? Name other large birds.

(c) Which of your bird acquaintances feed upon seeds? On worms? On insects in the air? On insects under the bark of trees? On fruit?

(d) What birds which you know run? Hop? Walk? Which ones get about in more than one way?

(e) What birds perch on the trunks of trees? etc. 


\section{XII}

\section{THE ROBIN}

NOTE TO THE TEACHER. - This study of the robin will continue during the whole of the spring term. It is not intended that it should be carried on for a week or two on consecutive days and then dropped. The different phases in the life of the robin - first appearance, appearance of the females, nest building, incubation, flight from the nest, care of fledgelings after leaving the nest - will be studied as they appear in the life of the robin. Studies of other birds, of flowers, and of trees will be carried along with the study of the robin. The children will be watching the robins every day, but only when there is something interesting to report will a recitation period, or part of a period, be given up to talks about it. The teacher herself must be as alert in observing as the children, and have as much or more to contribute to the recitation. She will give her observations if there is time for her to talk, or if these observations will materially contribute to the children's interest in the robin, but she must not rob the children of a chance to tell what they have seen.

See who will be first this spring to see a robin. [The older children will write down the date of its appearance, in notebooks made by them. A page or more in this nature notebook is devoted to notes on the robin, which the children make from time to time as something particularly interesting occurs. The teacher writes the date of the robin's arrival on the board for the younger children.] Notice the gay dress of these robins that are the 
first to come. These are the males. Describe their dress. What do they do on bright days? Where do they perch while singing? What is their song? Do they always sing the same song? Do they sing on the wing? What other sounds do they make? How do they call? Where do they perch when calling? For what are they calling?

What do the robins do on dark, cold, or even snowy days? To what places do they go for shelter? How can you help them on such days? What will you feed them? (Crumbs, bits of suet, or meal worms.) Where will you put their food? (If possible, out of the reach of cats. A window ledge is a good place.)

You said they were calling for the females; how can you tell when the females arrive? (Their dress is not as bright as the males' dress. They seem plumper.) Why is it well that they do not wear so bright colors as the males? (They are not so likely to be killed. If a female were killed, quite likely she would leave a nest of eggs unhatched, or helpless babies. Her color, being rather dull, will not attract so much attention while she sits on her nest.) Do the females sing? Do they utter any sound ? What? Where have the robins been? When did they 
leave here? Why? (Because they could not find food.) What food do they eat? (Worms, bugs, and other insects, grubs, berries, and early cherries.) Where do they find worms? How find them? (Their bright, round eyes see well.) What color are their eyes? How do they pick up the worms? (With their sharp pointed bills.) Have you ever seen a robin picking up a worm? Tell what it did. [If the children have not noticed how a robin gets a worm, set them at work observing, and ask them to relate their observations in the class.] What is the color of the robin's bill? How do robins get about on the ground? Find out. (They hop sometimes, at other times they run.) When they want to go very fast which do they do - hop or run? Do they ever walk? Notice how they watch for worms. Do they scratch for them? What do they use for pushing the dead leaves aside? (Their bills.) Watch them. What insects have you seen them eating? Where did they find them? Tell how they get berries from the bushes. How do they get cherries from the trees? Do they swallow them whole? How do you know they do not? (We find on the trees cherries which they have pecked.) Notice whether they eat good cherries or wormy ones. 
The robins have other work to do besides getting food for themselves. This is the month of May - a busy month with robins. What are they doing? (Making nests.) Where do they make their nests? In what part of a tree? (In the crotch, or angle formed by two branches, usually, but sometimes out on the branch.) What trees do they seem to like best? Why build in trees? (The leaves protect the nest from observation. They shield it from the rain and from the sun and from the wind.) How high in the tree are the nests? Of what shape is the robin's nest? Of what built? [The teacher should have several robins' nests gathered in the fall, after the robins have flown.] The typical robin's nest is made up of three parts: the outside, of weeds, roots, straw, and small sticks, woven together; the middle, of mud, held together by some fine material; the inside, of grass, with sometimes a few hen feathers and moss. Which bird made the nest? (The mother bird, or both.) What did the male do when the female built alone? (He watched the nest and sang, and sometimes went to meet the female, when returning with straw, etc.) How much did she bring at a time? (A mouthful. Then her mate watched her closely while she wove the material into the nest.) How could the mother 
give the mud this shape? (She sat down on her nest and pressed her breast against it, - now here, now there. You could see her tail moving around in a circle as she molded her nest.) How did she get the coarse material in shape for the outside? (With her bill and claws. Her claws and toes are her hands.) [Study of these as adapted to grasping and holding, if the teacher has a live robin. If not, it is enough to know that she does use her toes for fingers.] How long does it take to build the nest? (Three or four days; sometimes less.) When the nest is all done, what happens? (The mother bird lays some eggs.) How many? (One on each day until from two to six are laid.) Of what size are the eggs? (They are about the size of some of the little candy Easter eggs.) Of what color? (Bluish green.) Is that a good color for them? Why? The color resembles that of the leaves of the tree, so the eggs are not readily noticed.

Does anything ever disturb these eggs? (Sometimes bluejays, crows, blackbirds, or owls go to the robin's nest and steal all of the eggs.) What if the robins should see one of these birds near the nest? (They would raise a terrible cry, call their neighbors, and flutter about until the bird might be glad to leave.) 
Are the robins ever disturbed while on their nests? (Sometimes at night an owl will go to the nest, snatch off the mother with its bill, then eat up the eggs or even the baby birds.) Sometimes in the daytime a black snake will climb the tree, scare off the mother bird, then steal the eggs or baby birds. What do the parents do about this? (They fly all about the snake and try to peck it and drive it away, but it is not afraid of the old birds, and sometimes catches them, too.)

Do you know of anything else that steals robin's eggs? (Sometimes thoughtless or cruel boys take them. They have not the excuse that the owl, crow, and snake have, for boys do not need the eggs at all. The robins cannot hurt the boys-defend their nests against them. The boys know this, so they take the eggs.) What do you think of that?

What does the mother do with the eggs if they are spared to her? (She sits on them.) How long? (About twelve days.) Does she never leave the nest? (Only to get food and bathe. While she is gone, her mate sits on the nest.) Did you ever see a robin bathing? (A robin bathes in water every day.) How does it bathe? Where? [Watch and see.] Many people help the birds by putting fresh 
water in a pan upon a post where the birds can get it. Why not put the water on the ground? (Cats might get the birds.)

After the robin has been sitting about twelve days, what happens? How do the young robins look? (They are naked and blind, and seem to be nearly all mouth. When a little over a week old, for the first time they see their parents and brothers and sisters. They never know quite how ugly they look at first, for when they open their eyes their feathers have begun to grow.) What becomes of the eggshells after the birds are out? (The papa robin pushes them out of the nest with his bill, and he now cleans out the nest whenever it needs it.)

How do the baby robins spend their time? (Eating and sleeping.) What do they eat? How get their food? (The papa and mamma feed them.) Do they eat much? (They keep their parents hunting food nearly all the time.) How do the parents give the food to their children?

Since these birds eat so much, they must grow very fast. Does their home grow, too? (No; so the house is soon too small for so many big birds.) What will be done about it? (The birdies will have to leave. When about three weeks old they bid 
98 NATURE STUDY LESSONS FOR PRIMARY GRADES

good-by to their home.) How large are they now? How are they dressed? (Very much as their parents are dressed, only their vests are spotted instead of plain orange.) How will they get out into the world? (They must learn to fly.) Did you ever watch any young robins learning to fly? Tell what they did. How did the parents act? Watch for young robins learning to fly this sum. mer, and tell what they do. Do they learn to fly well?

After the young robins have left the nest, do they go back at night? (They never go back. But they are not old enough to feed themselves. The parents take care of them after they leave the nest until they learn to take care of themselves.) Tell what you have noticed about the parents feeding these big children of theirs.

If this was the first brood of the summer, the mamma bird may go to work immediately to build another nest and lay some more eggs. She usually builds this nest near the first one. Sometimes a mamma robin makes three nests in one summer and raises three families. She has little time for rest, aside from that spent on her nest.

What enemies have the little birds? (The cat 
is one of its worst enemies.) How can kitty catch the birds? What other enemies? (Squirrels and owls carry off the helpless little birds.) What can you do to protect them?

Next fall we will see how late in the season the robins stay with us. How long have they been with us already? Watch them all summer and tell in the fall what interesting things you have seen them do.

\section{XIII}

\section{THE RED-HEADED WOODPECKER}

At the beginning of the spring term the children are asked to watch for red-headed woodpeckers and report the first one seen, as they notified us of the first appearance of the robin. To make sure that the children know what bird they are to look for, the teacher asks: "How many know this bird?" "Tell how it looks." (It wears a red cap, a bluish black coat, with white skirts (when at rest), and a white vest.) The female dresses like the male, only her colors are not so bright, and she is a smaller bird. [Show a stuffed specimen or colored picture.] The red-headed woodpecker is late in coming. 
What bird have we been talking about? (The robin redbreast.) And what other bird have we been looking for? (The red-headed woodpecker.) How many have seen one? What was it doing? (Knocking on tree trunks, running up trees, or flying.) Why were the woodpeckers knocking on the trees? (They were making holes through the bark.) Why? (To get at the grubs or insects under the bark.) How can a woodpecker make this hole? (A stuffed specimen would be of use in studying the bill as adapted to its work; if this cannot be had a good picture could be used to advantage, for the children cannot get close enough to the bird to examine its bill. There is a good picture in Hooker's "Child's Book of Nature," Part II, and in "Birds" there is an excellent colored picture.) (Its bill is long, straight, and pointed.) How much noise does it make knocking? How does it sound? When it has the hole made, how does it get the grub? (It thrusts out its long, narrow, pointed tongue. The end of its tongue is hard and has little teeth pointing backward in this way - showing by diagram on the board. It can run this tongue out far beyond the end of its bill and do it very quickly. When a grub is once pierced by this hook it cannot 
get away, for the barbs hold it on. But sometimes an insect is too small to be pierced in this way; such are caught by a sort of glue that is on the end of the tongue. They get stuck fast in it.) [If there is any danger that the children may not understand the latter statement, a child might take a little glue on his finger and notice how all small particles that he touches with his finger cling to it.] Can you tell now why this bird is called a woodpecker? Does it harm the trees to be bored into in this way? (They do not often bore into a tree unless they hear a grub or bug under the bark.) What if these grubs were left in the tree? (They might kill it.) Do trees that are healthy have insects under the bark? (No.) What kind of trees, then, does a redheaded woodpecker peck? (Only those that need the woodpecker to take away the insects that injure them.) Did you ever see them peck at the bark of dead trees? Do you think they were there for insects? Strip off the bark from a dead tree and see if you can find insects there.

Upon what does the woodpecker sit while breaking into the grub's house? (It does not sit at all, it stands up.) How can it do this? (Have stuffed specimen or a good picture in the class to show how 
IÓ2 'NATURE' STUDY LESSONS FOR PRIMARY GRADES

the toes hold it. If neither is to be had, put a diagram on the board.) (It has four toes, two in front and two behind. They have strong, sharp, curved claws. These claws catch into the wood before and behind, and hold it firmly.) Does it use anything but its claws? [Children find out for themselves.] (It has a long and very stiff tail. The ends of the feathers are pointed, and these are pressed into the wood and prop the bird up, just as this brace - showing one - holds this board up.) Does it seem afraid of falling when running up a tree? (No, it goes with as much ease as you run on the sidewalk.)

Do the red-heads get insects in any other places than under the bark of trees? (They find them on the outside of the bark and on the leaves of trees, on the ground also.) How do you know? Where else do you see insects? (In the air.) Do the red-heads ever catch them while in the air? Watch and see. They catch beetles and wasps while on the wing.

Do they eat anything except grubs and insects? What? (Cherries, berries, apples, and pears.) How do they eat them? [Children observe.] Leander Keyser says that they sometimes dig out holes in the top of posts, in dead tree trunks, or in stumps, and hide fruit. He saw a red-head press a berry into one 
of these holes, then suck out its juice. Sometimes these birds catch a cherry or a berry on the fly, but usually they alight near enough to it to reach it with their bills. Do they swallow a berry whole? [Children find out.] Do they carry off a whole cherry? Find out.

Do you know of anything else that red-heads feed upon? (Once in a while, but not often, you will find a red-head boring holes into good trees for the sap.) Have you noticed these holes? How did they look? (They often extend around the tree in a circle.) It is another woodpecker that does most of the sucking. They suck the sap out of these little wells. After a while the wells fill up again, when the woodpeckers suck them dry as before. What little insects that like sweets do you know? Where might they go for them? (To these wells.) What might happen to them here? (The red-heads might make a dinner off them.) [Dr. Lockwood thinks this is one of the purposes of these wells.]

Do you think the red-headed woodpecker is a pretty good bird to have around? Why? (Review.)

What is the only harm we have found this woodpecker doing thus far? Ought we to welcome them when they come back in the spring? Why? Do they 
come at the same time as the robin? When did we hear the first robin? When the first red-headed woodpecker? Could you tell that he was here without seeing him? (Yes, by his drumming.) How did it sound? ("Tap! tap! tap!" very fast, then "tap! tap!" very loud, with a pause between the two taps.) What did he use for his drum? (A dry limb or sometimes a shingle on the house.) What did he use to beat the drum with? (His bill.) Does he never sing? (No; and he is too happy to keep still, so he beats a drum to make music.) Does he have but one drum? (Each woodpecker has a favorite place where he goes to drum. One spring one wakened me very early every morning by drumming on a shingle in the roof just above my head. Woodpeckers drum in other places, too, as they fly about getting their food.) Find out whether they do most of their drumming in the morning or in the afternoon. How early do they begin? When you hear one, run and ask your mamma what time it is. Do they drum very long at a time? Do they drum constantly, or stop to rest a little once in a while? What do they do when resting? The drumming seems to be a call to the mate. See if the children arrive at this conclusion by noticing that the bird acts as if he were listening, and later is some- 
times joined by the female. Does he drum at all when his mate is with him? (Yes, and she seems to think him a fine musician.) Is this the only sound you hear a red-headed woodpecker make? (He makes a shrill, lively sound, in which there is no music.) See if you can make it. You may tell all you know about the music of a red-headed woodpecker. (Review.)

Where do red-headed woodpeckers sleep at the end of their long, busy day? [Leave the children to find this out for themselves if they can. Let them watch near a nest if there be one near their home.] (They sometimes, early in the season, sleep in holes in trees, but Leander Keyser says that they usually sleep on an upright or oblique perch, clinging with their stout claws, with their heads pillowed in the feathers on their backs.)

After the red-headed woodpecker has called his mate they two go to work building a nest. Where? (In the trunk of a dead tree that is not too soft or in a branch, a fence post, or a telegraph pole. When made in a branch it is usually on the under side.) Why? How do they make it? (They cut out a round, smooth, straight hole right in front of them, with their bills. They make it large enough around so that the 
bird can go in. When the woodpecker has gone in five inches or so - show distance by a mark on the board - he begins to work downward, making the hole larger and larger as he goes down ten or twenty inches - show by line.) [If not possible for the children to see a nest, the teacher should give them a clear idea of it by a diagram on the board.] You have learned that the mamma robin sometimes builds the nest alone. Which is the harder to make, the robin's nest or the red-headed woodpecker's? (The red-head's.) Will the mamma have help, do you think? (Yes, the papa bird does half of the work.) Can they work together? Why not? (The mamma bird often works just about as long as the time you spend in this class, - twenty minutes, - then she flies to an upper limb and calls her mate in her shrill voice. When he comes she seems to tell him how much she has done, and they talk over their plans together. Then the papa bird flies to the nest and works about as long as the mamma worked, while she flies away for food and rest. Then the papa bird calls the mamma bird and tells her about his work, etc.) How do they get the chips out of the nest? (Carry the coarse ones out with their bills.) How is the nest lined? (The fine wood or 
sawdust falls to the bottom of the nest, and this forms a soft bed for the eggs.) Is this a good kind of nest for a bird to have? Why do you think so? (It is protected from the storms, and from the birds and animals that trouble the robin's nest.) What ones? But there is one animal that troubles the robin's nest, which can easily get into this nest. What is that? (The blacksnake.) Quite often it steals the woodpecker's eggs or birds.

Do these birds go to all this work to make a nest every year, or do they use the same nest year after year? (They make a new nest. They do not use a hole which they find already in a tree.) Can you see the eggs or the tiny woodpeckers in the nest? Why not? How many eggs? (Six, usually.) How do they look? (They are more nearly round than are the robin's eggs and are larger than hers. They are pure white and very smooth.) How can you tell when there are little woodpeckers in the nest if you cannot see them? (If you are near the tree, you can hear the babies cry. They are big eaters, and nearly all the time they are teasing for food.) Who feeds them? (The mamma and papa.) What do they feed them? (Bugs, moths, grasshoppers, etc.) When they are big enough to fly about, how 
can you tell them from their parents? (The first summer their heads are not red, but, instead, a very dark gray, and their wings are spotted black and white. The white on their breasts is not pure white, but dirty-looking.)

Do these brothers and sisters have good times playing? (Yes, and the father and mother play, too.) Children watch them and tell what games they play. And, if you have a chance, watch one during a shower and see what it does. [The teacher should call for their observations and relate her own, throughout the summer term and again in the fall. The children should be taught to be very wary in watching birds; try to keep out of their sight as much as possible, and keep quiet.]

What other woodpeckers have you seen? Describe them. What one is often seen on the ground? (The flicker.) What ones are with us through the winter? (The downy and the hairy woodpeckers.) 


\section{XIV \\ THE COMMON CROW}

How do you keep warm this cold weather? How do we protect horses, cows, and sheep from the cold winds and the snows and sleet storms? What do we do for the chickens, geese, ducks, and turkeys? But there are some birds for which we do not think of providing shelter, even on the coldest days or in the most severe storms. What are they? Let us see if we can find how one of these birds - the crow - lives through the winter. Do you all know the crow? How can you tell it from other birds? (It is large, and has a glossy black coat. Its bill, legs, and toes are also black. Instead of singing or chirping, it says "Caw.")

What keeps this queer bird from freezing? (Its feather coat.) How is it adapted for keeping out the cold and snow and shedding the rain? How are the legs and toes protected when roosting?

Where does it make its home in the winter? (Usually in evergreen trees.) Is this a good place? Why? (The thick foliage protects it from the cold winds and it is hidden from the view of those who 
might wish to shoot it.) Does it need anything besides a good coat and a sheltered home to keep it alive in the winter? (It must have food.) What does it eat? Let us watch, this winter, and see if we can find out for ourselves. [The teacher should frequently ask for the results of the children's observations and give them her own, then they will think her questions are not idle ones. The children may find that it eats mice, carrion, hens' eggs, corn, acorns, nuts, frozen apples from the boughs of trees, and the fruits of poison ivy, poison sumac and other sumacs, sand, and gravel. They may discover also that it drinks a great deal of water. Careful observations made by the children will arouse in them a more than transient interest in the object studied. This the teacher should work for constantly, and feel quite sure that her work amounts to but little if the children are not interested enough to watch, outside of school, the movements of the animals studied.]

Let the children tell what they have observed in regard to the manner in which the crow catches and kills the mice. What does it do with the hens' eggs? Where and how does it get the fruits of ivies and sumacs? Why eat sand and pebbles? 
[Recall what they discovered in the chicken's gizzard.] How is the bill fitted for getting this kind of food? (It is long, pointed, hard, and strong.) Does it find plenty of food? Did you ever hear this expression, "As poor as a crow"? Many times crows have a hard time in the winter to find enough food. They become very poor and sometimes they even starve to death.

Can you get close enough to crows, usually, to tell how fast they eat? Why are they so afraid? Why do men and boys shoot them? Are they any more afraid of a man who carries a gun than of one without? How can crows get a chance to eat if they are watching for men all of the time? (They have sentinels out watching. These warn the flock of any approach of danger.) What kind of warning do they give? How is this warning received by the crows? What follows?

What takes the crow away from danger? (Its strong, large wings carry it away.) Does it fly high? How do you know? Does flying seem to tire it? Study the adaptability of its wings to flight. Do crows fly singly or in flocks? [Children notice.] Is this so at all times of the year? We will notice how they go next spring. 
Have they no other way of getting about than by flying? (They walk on the ground.) Have you ever seen them walk? Were their steps long or short? How did they hold their bodies? Do they ever run? Do they hop? Why were they on the ground? Did you ever see a crow's tracks in the mud or in the snow? How many tracks did each foot leave? Picture on the board.

What is the crow's work in the winter? Is this all it does the whole year through? (No, in spring it builds its nest.) How early? Did you ever see it building its nest? Have you ever seen a crow's nest? Why do we so seldom see one? (They are built high up in trees - very often in evergreen trees.)

[Have a nest in the class if possible.] This nest was taken from a tree after all the little crows were grown up. The crows never use the same nest for two seasons, so we know they will not need their old home any more.

Of what is it built? (The outside is made of twigs and sticks, the inner wall of grasses, leaves, and bark from cedar trees or grape vines. Some of their nests are lined with hair.)

Early next spring we will begin watching the 
crows to see if we can find in what trees they build their nests, and how they get the sticks, etc., to the trees.

How do you know that the crows are about when you cannot see them? (They flap their wings noisily and cry "Caw! caw!")

Abbott says that crows have twenty-seven distinct cries, each of which is accompanied by a different act. [It would be interesting for teacher and pupils to observe closely and see if they notice any connection between the movements of the crows and their different notes.]

\section{XV \\ THE SCREECH OWL}

(A Winter Study)

What birds have been with us all winter? Some of these birds are more often heard than seen; which are these? (The owls.) Why do we see them so seldom? Have you ever heard them? What sound did they make? (Some cry "Hoo! hoo!" others make a sound variously likened to "the coo of a dove with the sweetness left out," "the whining of a puppy," "the grating of machinery," "the wailing of a little child.") 
We shall talk of the ones that make the wailing cry. On account of the unpleasant music which they make they have been given a name of which they cannot be very proud. What is it? (The screech owls.)

Have you ever seen a screech owl? What was it doing? What kind of looking bird was it? (Perhaps of a grayish color, or it may be of a rusty red color, with lighter and darker markings. It is from eight and a half to ten inches long. The children show this by placing the hands so far apart.)

At what time of day was it when you heard the screech owl? Was it talking in its sleep? (No, the night is the busy time of day for the screech owl.) About what is it so busy? (Getting its dinner and breakfast. These are such hearty meals that it needs no luncheon in the middle of the day.) What do they find to eat? (Mice, English sparrows, and other small birds, eggs of birds, frogs, small snakes, fish, grasshoppers, crickets, beetles, moths, the cockchafer so injurious to fruit trees, and cutworms, which, like the owl, turn their night into day.)

At what time did you say the screech owl catches the mice? (At night. Both the owl and the mouse like to hunt after dark.) How can the owl see the 
little mouse? (It has large, bright eyes. These are in front of its head, so that it can fix both upon one object.) Study the eye. How large the pupil is! Why? Of what does it remind you? Notice the yellow curtain - iris - which surrounds this pupil. Only a little of it shows at night. Why not? Each eye is surrounded by a disk of short, stiff feathers. Have a screech owl in a cage in the class if possible.

Let us see how screech owls catch and eat mice. Where do they find them? (In shocks of corn, in their field nests, about barns and corn cribs, running over the snow.) How do they catch them? (Swoop down upon them and grasp them with their long, sharp claws.) Study the very sharp, long, strong, curved claws on the strong flexible toes, as to their adaptability for catching and holding prey. Notice the reversible outer toe. How does the owl use it? We are very glad that the owl kills the little mouse almost instantly.

How does it eat the mouse? (Often tosses it up with its bill in such a way that the head comes down into the owl's mouth; then it makes one big gulp, but often a second is needed before the mouse is down, tail and all.) Are you surprised that it eats the 
whole mouse? What parts should you think it might better have left out? (The hair, teeth, and bones.) Examine these little balls found at the foot of a tree in which an owl had a nest. [The children find here hair, teeth, bones, feathers, etc.] Where could these have come from? The owl, a few hours after eating a mouse or a bird, throws up one of these balls. Look in the owl's cage for the balls.

Why do not the mice get out of the owl's way? (The owl makes almost no noise when flying, on account of the soft feathers which line the wings and cover the body.) Study the wings with reference to their fitness for noiseless flight.

Owls often know when a mouse is near, even though the mouse be out of sight. How is that? It hears it. Where are its ears? [The children will call the tufts of feathers on the top of its head the ears. If you have a stuffed specimen, let them discover that there are no ears there. They will find large ears, covered by feathers, just outside the disk of feathers surrounding the eye. This is the only bird that has an outer ear.] Notice how the feathers are arranged just outside the ear. How does this help its hearing? Why is it well that the ears are covered with feathers? 
What else does the owl eat? (Small birds. These, too, it kills almost immediately.) How does it catch them? Does it swallow them whole? (No, it tears them in pieces.) Do the birds know that the owl is their enemy? How do they treat it? (If they find an owl in the daytime, they make a terrible commotion. All the birds gather together and scream at it, flying as close to it as they dare. When it flies away they follow it, calling it hard names.)

How does the owl catch its other food? How much of this food can it get in the winter? Does it go out hunting on the coldest nights? (In the warmer weather it often stores up enough food to last it a week or more, and mature owls often go a week without any food, not seeming to mind it.)

What, besides food, does it need? (Water.) It is a great drinker. Owls are sometimes caught by cutting holes in the ice. They come here to drink and are captured.

Is the screech owl's coat well fitted for a bird which must make a living in the winter as well as in the cold, damp nights in warmer weather? Study carefully the plumage of the owl as adapted to its protection from cold and damp. Unlike many other birds, the legs are covered their whole length with feathers, 
and the feathers even run down each toe. What care does it take of this thick, soft, light coat? (It bathes very frequently, and enjoys its bath greatly.)

Where were the screech owls which you saw? (Peeping out from the hollow of a tree or among the thick foliage.) Very likely you nearly passed an owl without seeing it, for they keep very quiet and do not cry out if they see a person coming. Its color helps the owl to escape notice. How is this? Why do its bright eyes not attract the notice of people? (They are nearly closed in the daytime.)

Find out all you can about how the owl makes a living.

SPRING STUDY OF THE OWL

We have learned how the owl makes a living for itself. Does it never care for others? There must be little owls sometimes. When do you think the little owls come? (In warm weather, in May or June.) Have you ever seen an owlet? Where was it? Perhaps in a rotten hole in an apple tree. How far from the ground was the hole? (Not higher than this room, ten feet.) How is the nest made? (The owls choose a hole in a tree, - they do not make one, as does the woodpecker. This hole is often not lined at all. There is rotten wood in the bottom, 
and often dry leaves which have been blown into it; but sometimes the mother adds a few feathers from her breast, and sometimes the parents line the nest roughly with dry grass.)

What kind of eggs are laid in this nest? (Four or more round, white eggs.) Which bird sits on the eggs? (The female; and during the day the male, too, sits there if the nest is roomy enough; if not, he chooses a hollow tree near by.) How long does it take the eggs to hatch? (About one month after the first egg is laid, the little owls are out of the shell.)

How do they look when first hatched? Did you ever see one? [If possible, the children should see one before the season is over. It is a sight they will never forget.] (The owlets are at first covered with a yellowish white, downy coat. They look like fluffy balls.)

How long do they stay in the nest? (About a month. Then they scramble out on the branches. They can climb like cats.) Did you ever try to catch one? What did it do? (Snapped its bill viciously.)

How are they cared for, while growing up? (Both father and mother are kept very busy providing these hearty children with food. It would be a sad thing for the babies if one of their parents should be killed 
ere they were old enough to provide for themselves. We hope for their sake that this may never happen. Before cold weather comes, every owlet is grown and able to care for itself.)

Frequent reviews should be made by topic, as, "Tell how the eyes fit the screech owl for work at night," or, "In what respect does the owl resemble the cat?" (Its head looks like the cat's, it hunts at night, it likes mice and birds to eat, it can climb, etc.)

\section{XVI \\ THE ENGLISH SPARROW}

This is a bird which we may study at our doors all the year round. No inducement need be offered to bring it near, it never fails us. Since the bird is so common we should know its habits well, but in truth we know little about it. Juncos and sparrows that we love for their music are often called by its name, because so few take pains to identify this very common bird.

How can you tell the male from the female? (The male has much chestnut in the coloring of its coat and it wears a black goatee. The female wears a light-colored dress in the coloring of which is no chestnut, and it has no black on its throat.)

Where does the English sparrow live? When 
does it leave us in the fall? (It stays all winter.) Most of the other birds have to go south; how can the English sparrow stay? (It lives upon grains, crumbs, and refuse that it finds in the streets.) Where does it stay during the winter? How does it get about upon the ground? Watch for its tracks in the snow. How does it protect its feet in the cold weather?

Where does it build its nest? What kind of nest does it make? Of what does it build it? How many eggs does it lay? What color? Which of the parents feeds the young birds, or do both work? Watch each as it brings food to the young, and notice which makes the more ado about it. Notice carefully what is fed to the young. Watch the fledgelings as they leave the nest, and describe what you see.

Why are there so many more of the English sparrows than of the songsters we love? [The children will tell how the English sparrows drive the other birds away and take their nesting places from them.] The wrens, bluebirds, and martins all suffer at their hands. Notice, too, how late in the season some of these birds are still building nests, even in cold weather. Sometimes the young are raised and 
hatched even in the winter time, so industrious is this bird. The best way to drive the bird away is to destroy the nests before the young are hatched. It would be cruel to harm the helpless young birds.

How could you tell without looking that the English sparrows are about? (By the constant chirp.) What is their song? (They have none.)

What are their good points? Their bad points?

\section{XVII}

\section{CATERPILLARS}

These numerous little visitors are a very interesting study for all grades in our public schools. Few people see in one of these odd little creatures a whole, wonderful life history. This is not the fault of the caterpillar, however, for its manner of life is quite open to the inspection of any one who cares to know of it, and it is certainly a pleasure to be able to say to one of these little folks: "How do you do? I am glad to make your acquaintance, for I knew your mother, whom you never saw. She showed her devotion to her children by making the best preparation possible for satisfying their babyhood wants. For before your life was begun hers was ended; so 
she made it possible for you to care for yourself. I saw her one day seeking a home for you. She chose a place which she knew you would like, and there, on the leaf of a plant like the one upon which you are now feeding, she laid the egg from which you came. She did not crawl up the stalk, but flew lightly down to the plant. Does not that seem strange to you? Do you remember how happy you were when you crept from your shell and found your dinner waiting for you? Why did you eat up the house in which you had been staying? Did you fear that an enemy, on seeing that, might know that you were near? Eat away, my little fellow; that is your business at present. No one should call you a glutton. Under the same circumstances your accusers would do no better. You must eat, in two or three weeks, enough to last you the remainder of the fall, and all winter, besides. No wonder you give yourself up to business so thoroughly."

As the caterpillar eats away, some little child, perhaps, picks the leaf on which it rests and places both in a box, or he gently brushes the caterpillar into the box, puts fresh leaves beside it, and carries it home or to school, where he may watch it. That all the children at school may see all of a caterpillar's 
movements well, it is put into a glass which is covered with netting or perforated paper. Two or three times a day the children supply it with fresh leaves, removing the wilted ones and occasionally cleaning the glass. The little captive seems quite contented so long as it has plenty of fresh food of the kind that it likes best, and a good appetite.

Often we find caterpillars on the walks or in the road; these must be tested with a variety of food until leaves are found which they will eat. The hairy caterpillars which I found this summer contented themselves with the leaves of the smartweed or a closely allied plant. The plantain was, also, accepted by several. But whenever possible to know its choice, the caterpillar has been fed the food which it likes best.

Some of the caterpillars may begin spinning, or otherwise changing, the day on which they are captured. When we find one spinning at school, we pass the glass to the children for their inspection, taking care not to disturb the little worker. Some lesson may suffer for this interruption, but the children have a bit of experience all their own, which they would not care to part with, and school is made pleasanter for this little break in the routine. 
Long after most of the other lessons are forgotten, the children will look back with pleasure upon these happy moments of discovery.

It has been our good fortune twice this fall to see a hairy caterpillar divesting itself of its hairs that it might weave them into its coverlet. It seemed to require no effort. Did it pull them out or bite them off? I am not sure. It did not appear to carry them in its mouth. How, then, did it carry them? This question must be solved by further observation. How deftly it wove those hairs into its cocoon, spreading them very evenly over its surface! How could that clumsy-looking body, with the still clumsier fleshy feet, move over that web with never a trip or a break of the dainty silk? In what a businesslike way the weaving was done, - the thread coming from its mouth as needed, and placed in position by movements of its head and front legs. When the top of the cocoon is to be thickened, it, lying within, turns upon its back and weaves away as if this were its natural position: It really never seems awkward when making its house, yet this is the first one it ever built, and it will never have an opportunity to build another.

Several of the caterpillars use leaves as a par. 
tial or a complete outside cover. These are woven firmly together and lined with silk.

Once, in a very close little home, in which there seemed not room enough to stir, the caterpillar turned completely around, end for end. It moved with dignity and grace. We could not tell exactly how, for we did not understand its intentions at first.

One of the caterpillars which we watched snipped off small portions of the leaves in the glass and wove these into its outer cover. They made the cocoon look very pretty, scattered regularly over its surface. Why did it do this? Has a caterpillar an eye for beauty?

I have named but few of the many queer things which we noticed while the hairy caterpillars made ready for their sleep.

The glasses which held the cocoons were placed in a dry cellar late in the fall, where they were kept until early spring, when they were again watched by the children for the housebreaking.

In the fall work on the caterpillars, the children note the changes and give orally the history of each caterpillar so far as they have observed it. They also write portions of this history. They 
make drawings of the caterpillar and its chrysalis, or the cocoon. The chrysalis and caterpillar are molded in clay and placed side by side on a plaque.

The older children can do more. They can keep a book, which they might name "Life Histories of Caterpillars." They number the glass in which each little prisoner is confined, and write on the first page a few facts about Caterpillar No. I, viz.:-

(a) Hairy or smooth.

(b) Length, color, and any striking characteristic in appearance; number and position of legs.

(c) When and where found. Food on which it is fed.

(d) Any peculiarities in its actions.

The next page is devoted to The Cocoon or Chrysalis of No. I.

(a) Length and shape of the cocoon and manner in which it was made; also time of making.

Or description of the chrysalis, with account of the gradual change and date of its consummation.

The third page is devoted to The Moth (or Butter$f(y)$ of No. I.

(a) When did it come out? Description of the method of releasing itself.

(b) Description of the moth (or butterfly). 
(c) From what flowers does it get its nectar? Color of these flowers?

On the fourth page is given a record of The Eggs and Growth of No. I.

(a) Where were the eggs laid? How many in a place? Color? Form? Size?

(b) How long did it take the eggs to hatch?

(c) How long does it take the caterpillar to mature? How many moultings?

It may be some time before this page is filled out, but watchfulness will reward the patient seeker. Quite likely more than one page may be needed for some of the descriptions.

Many cocoons are found in the fall. What caterpillar made them is a mystery, so our first entry in the book will be on the page devoted to the cocoon or chrysalis.

This book may be used season after season, until every caterpillar is known through its whole series of changes.

It is a wonder that more boys and girls living on farms do not make a study of caterpillars, learning to distinguish the harmful from the harmless. Through knowledge of the habits of those which are injurious to trees, vegetables, etc., the eggs of their moths or butterflies might be found and destroyed. 


\section{XVIII}

\section{THE CABBAGE BUTTERFLY}

Have you seen butterflies in a "cabbage patch"? Of what color? What were they doing there? Watch them closely and see if you can find out. (They were laying eggs.) Where did they lay the eggs? What was their color? Why was it well that they were of this color? How many were there together?

The teacher might well bring to the class a head of cabbage on which are some of these eggs. Keep in a shady, cool place where the leaves will not wilt, and allow the children to look at the eggs every day.

Encourage them also to watch those on one head in their gardens at home. In about ten days from the time the eggs were laid they will hatch out into tiny green caterpillars. Is it well for them that their color is green? Why? What do they do as soon as they come from the egg? (Go to eating the leaves.) Why did the mother lay the eggs just where she did?

A few of these caterpillars may be put into a glass and supplied with fresh leaves every day. The top should be covered with paper in which there are 
holes for the air to pass through. The children will feed the caterpillars and watch their growth. They grow to their full length, one and one-half inches or less, in about three weeks.

What happens when they are fully grown? (They hang themselves up.) How? Where does the silk come from? (From the mouth.) In the body of the caterpillar are two long bags which hold a sticky fluid. This fluid flows through a tube which ends in the middle of the lower lip. The fluid hardens as soon as it comes to the air.

Does the caterpillar hang with its head up or down? Then what happens? (It throws off its caterpillar skin.) Make a picture of it as it hangs now.

The children note the day when it goes into its chrysalid state, and watch for it to come out. They will need to watch about eleven days if the study is begun early in the season. It will be a joyful moment for them if they are so fortunate as to see it leave its home. How does it go to work to get out? (It begins to move about, a slit comes on its back, and it puts its head out; then the rest of its body comes out, and the little green house is left empty.) 
The children now have the whole life of the cabbage butterfly learned from their own observation. They will never forget it. It helps them to interpret the life of all caterpillars.

They will gather, feed, and watch other caterpillars. Not all of them will change into butterflies - some will become moths; and by comparison they will find these differences between butterflies and moths : -

(a) A butterfly flies in the daytime, a moth by night.

(b) A butterfly holds its wings erect when at rest. The wings of a moth lie flat, or slant like the roof of a house.

(c) A butterfly has knobbed feelers. A moth's feelers are not knobbed.

\section{XIX}

\section{THE MILKWEED CATERPILLAR}

HATCHING OF THE EGG

[What the older boys and girls may see if they look closely.]

On the afternoon of August 12 we found an egg of the milkweed butterfly on the center of 
the under side of a milkweed leaf. It was cylindrical, with a conical top. In color it resembled a pearl.

In the morning, three days later, the cone at the top of the cylinder was found to have turned black or purple, and later in the day black specks were seen in the cylinder. About twelve o'clock two bright dots, looking like bubbles, appeared on the purple dome, and kept shifting from one point to another. Suddenly there was a bright flash which looked as if a blow from within had cracked. into many pieces the dome, but it was not broken. There were now seen to be rapid motions inside the egg. The dome looked to be made of dainty silver rafters with still daintier crosspieces. Now the jaws of the imprisoned caterpillar began cutting the silver rafters at the base of one side of the dome. The light which was admitted changed the silver rafters to rows of beads, - red separated by short gold ones. A large hole was eaten in the side of the cylinder, then the black head of the tiny caterpillar was thrust out, followed by its white body, which bore a mere suggestion of yellow rings.

The shell, after the caterpillar had left it, was 
beautiful beyond description. It was like rare filigreed silver, the pattern being the daintiest of feathers.

The caterpillar nosed about for a few minutes, then went back to the shell and took a few bites of it; left it, as if its freedom from cramped quarters made it too happy to eat, but in ten minutes returned to it again and ate voraciously for five minutes or so; then after further investigation of its premises returned to the egg for a larger meal.

The day after this little caterpillar came out, it was killed by kindness. The teacher moved it to a fresh leaf. It was too young to be disturbed, and died.

\section{MOULTING}

On August 6 of the following year we procured a milkweed caterpillar not more than one fourth of an inch long. It was eating round holes in the milkweed leaf. It was light green, with yellow and black transverse stripes. The head was black. On the 9 th of the month two black horns were noticed on the front of the head and two shorter black ones on the back of the posterior extremity.

Two days later the light green color of the caterpillar had changed to bright yellow, of which there 
were double rows, branching low down on the sides. On this morning it attached itself to the side of the jar by a web which it wove, and there it hung motionless, head downward, for some time. At half-past one o'clock it began the task of disrobing. It first drew in its head until it seemed heavily hooded, and its true feet seemed drawn together under its chin; then began a series of shrinkings backward within itself, - apparent chokings, shiverings, tremblings, and gaspings, the body swelling out and then contracting. The head gradually sank farther back into the hood, leaving only a tiny yellow triangle. The greatest movement was now noticeable at the posterior extremity. The skin there stretched as if it would break, and became so thin we could see through it. At last the old skin at the front broke and the caterpillar worked out in front, pushing the skin back as it worked forward until the old coat came off at the back. Then the caterpillar threw its head about from side to side until the old headpiece dropped off. This changing of the coat occupied one hour. Occasionally the caterpillar rested. After the old headpiece had fallen off the caterpillar went back into its web and rested about twenty minutes, then ate up the coat it had just shed. Within two or three 
hours after it had shed its skin, it went to eating the fresh milkweed leaves.

\section{THE CHRYSALID}

The following year we had many milkweed caterpillars in glasses and watched their growth.

One morning one of our large caterpillars wove a web for a path and went to the top of the glass, which was covered with a perforated paper. Here it remained as if making plans for its change. The middle of the afternoon it underwent agonizing contortions. It threw its head to one side and then to the other, and then drew it in. The "feelers" were working nervously as the body worked. Late in the afternoon it let go its hold on the cover and swung free, being held to the cover by its hind feet, which were fastened in the web it had made. In this position it remained quiet part of the time, its head turned to one side, and part of the time wriggling to get free from its old coat. In the night it changed to a beautiful light green chrysalis. We could see the colored stripes of its coat through the thin cover. The dome-shaped top was narrower in front. The dome was separated from the body of the chrysalis by a narrow black line, above which was 
a row of small white dots interspersed with eight larger dots. Just above the larger end of the chrysalis, eight yellow dots, occurring at regular intervals, began to show. At the top there were six black dots, extending, in twos, toward the front from the point of attachment. The next morning all the white on the chrysalis was changed to gold, and a gold dot appeared on each side toward the front.

We had not seen the change from the caterpillar to the chrysalis. This was a disappointment, but later we saw what we had so regretted missing. This caterpillar swung off at six o'clock in the evening. I was up at half-past four o'clock in the morning. It was gnawing at its feet industriously. Occasionally it threw its head back. There was a great contraction and relaxation of the muscles between the black and white rings, occurring every second or so at the last. At the end these movements became very violent, the skin burst open on the back, near its head, and was worked backward and off, where it finally fell to the bottom of the glass. The chrysalis swung around, first a few turns to the right, then a few turns to the left, thus forming the strong, twisted thread by which it hung. It became a chrysalis at half-past five o'clock in the morning. 


\section{THE HOUSEBREAKING}

Twelve days after the caterpillar became a chrysalis, the chrysalis became a beautiful brown and black butterfly with white markings - the Monarch, or Milkweed, butterfly. The change, at the end, was very gradual. Two days before it occurred, the chrysalis had become of a lighter green; a day later, the orange and black showed through the thin chrysalis shell; then three shining points appeared on each side, extending from the center toward the bottom. In front the veinings of the wings were now visible, then the limits of the wings were plainly marked off on the sides. The margins of the wings broke through a little. While we were out of the room it came out, leaving its transparent chrysalis shell swinging empty. This was a disappointment. But the last chapter, it is hoped, will be recorded later. 
PART II

\section{PLANT LIFE}





\section{I \\ IDENTIFICATION OF FLOWERS}

Here, too, as well as in identifying birds, the games may be used in the first grade with profit and pleasure, e.g.:-

I. "Flower Game" in "Kindergarten Chimes," Kate Douglas Wiggin, p. I I 5 .

2. "Smelling," in the same book, p. I07.

3. "Guessing Game," p. 108 in the same book, may be altered in meaning a little so as to become a flower or a leaf game. Each child has a flower pinned upon his breast, and takes the name of the flower he wears; so the "who" in the third line refers to daisy fleabane, or oak, perhaps.

4. In "Touching," a game in the same book, which reads in the second line, "Now take the thing we give you," substitute flower.

[For similar games see "Songs for Little Children," II, Eleanor Smith, and "Merry Songs and Games," Hubbard.] 
5. A pupil, or the teacher, describes a flower which he is thinking about; the class name it.

6. Each of several children is provided with a flower - no two alike. A few children form a ring in front and sing, e.g.:-

"We're calling to you for a daffodil,

A daffodil, a daffodil ;

We're calling to you for a daffodil,

And here is one."

or

"And there is none."

As soon as the name of the daffodil is spoken, the child who has that flower skips forward and enters the ring, or if she does not respond, her flower is given to another.

\section{II}

\section{THE NASTURTIUM}

\section{(A Fall Study)}

How do you know the flower? (By its color, shape of its blossom, its fragrance, its taste, and its peculiar leaf.)

Each child is provided with a blossom. They examine it for the purpose of describing it accurately, so that one unacquainted with it would know it 
were he to come upon it. The points in which the children will be interested are these :-

(a) The variety in colors of the different flowers, the variety in one blossom, the markings of the petals. Out-of-door study: What besides people does the color attract? (Bees and humming birds.) Notice what these do when they come to the flowers. Find what it is they are seeking in the heart of the flower. (The juice in the long sac.) We call that the nectar. Taste of it. How do you like it? See if the sac is full. How can the humming bird reach it? the bee? Watch a bee as it leaves a flower. What is it carrying away? (Yellow dust.) On what part of its body does it carry it? From what did it come? Where does the bee go on leaving this blossom? Watch to see.

Notice in what direction the lines on the petals extend. Can you think of any reason for this? (They show the bees the way to the nectar.)

(b) The shape of the petals. What reason can you see for the broader upper petals? The overlapping of the edges of these petals? Of what does it make you think? (The roof of a house.)

(c) How the flower is held. Can you see any reason why it is held so that it opens at the side 
instead of at the top? (The rain cannot get in to spoil the nectar and the pollen.)

(d) The development from bud to blossom. How is the bud protected? Are these sepals of any use to the flower after it blossoms? Of what use? In which is the stem longer, the full-sized blossom or the tiny bud? Can you think of any reason for the longer stem of the blossom? (To attract bees, the blossom must be well above the leaves. The bud has nothing to offer to the bees and humming birds.)

(e) The development from flower to fruit. Notice all the changes in the flower, - the drying up of the petals and the sepals and the falling of the same; the growth of the inside of the flower - the ovary - until it finally matures, and turns brown. Where did you find the blossom, above or below the leaves? Where do you find the ripened seeds? How did they get down there? (The children will notice that the stem has twisted, in a curious way, so as to bring the seed pod under the leaves.) Can you think of any reason for this? (Perhaps it is to make room for the flowers, or to protect the seeds from the rain and the sun and from enemies that might like to eat them.) Taste of one of the seeds not yet 
ripe. What do you notice? Is it well for the seed that it has a spicy taste? Of what use is the seed to us other than giving us new plants? How many seeds in one pod? How are the seeds scattered? Will plants come next year from these seeds that are scattered? (The home of this plant is in a warm country, where the plants do not freeze after they sprout. They cannot bear our cold springs, so we save the seeds and plant them when the weather becomes warm.)

(f) The dense foliage. Describe the leaf. The stems of the young and of the older leaves. Of what use are the leaves to the little buds and to the seed pods?

NotE. - This is not intended to be an exhaustive study of the nasturtium. A fuller study would be made in the higher grades, including the cross-fertilization of the plants.

\section{III}

\section{THE MORNING-GLORY}

(A Spring Study)

Have you planted any flower seeds this spring ? What ones? [Among others quite likely the morning-glory may be mentioned.] Have you any morn- 
ing-glory seeds? You may bring some to school to plant, that we may have their pretty leaves and blossoms in our windows. [If the children have not the seeds, the teacher will furnish them.]

On the following day a number of seeds are placed in a dish where all can see them well. Notice their colors. Notice their shape. What gave them this queer shape? If they have not noticed the seed pod, they will be told that we shall find out later.

The teacher has in the class two wooden starch boxes, or other boxes, filled with rich soil. The girls plant seeds in one box and the boys in another. See which will have the better plants. Each is labeled. What do you expect from these seeds? (Morning-glory vines.) What care must the seeds have? (They must be kept warm and must have water.) How much water? [Appoint one careful girl to care for the girls' box of seeds, and a thoughtful boy to care for the other box.] The boxes are now set away. Where shall we set them?

Now each child is supplied with a morning-glory seed and a pin. Would you like to find what is inside this seed? You may take off its outside coat. (We cannot, it is fastened on so very tightly.) 
What shall we do to the seeds to loosen the outside coat? (Soak them.) I will soak them over night in warm water and see if that will loosen their coats. Is it well that their coats cannot be easily removed? Why? [On the following day the soaked seeds are taken to the class. Each child is provided with one and with a pin.] You may see now if you can remove the seed's coat. Be very careful not to injure what is inside. What do you find? (Underneath the coat is a layer which looks like light-colored jelly.) And what is inside the jelly? (Two tiny white leaves, all crumpled up, and between the two, and protected by them, is a little white stem.) Spread out the leaves. Why were they so crumpled? (If they had been spread out as they are now they would have taken up much more room. They were packed in as closely as possible.) Did you notice any jelly in the dry seed? Scratch a little of the coat off these dry seeds. (There is no jelly here, it is a hard substance.) What is this hard lining of the coat which turns into jelly when soaked? What do you expect these little stems and leaves to do? (To grow.) And what must they have to make them grow? (Food.) Where will they get the food? (The roots will 
gather it for them from the ground.) Where are the roots of this little plant? (It has none, yet.) What will feed it until its roots grow? (This jelly which is all around it.) Why did not the little plant begin to grow in the winter, in the paper in which we found it? (It cannot take hard food. Its food must be dissolved for it before it can take it.) Then what must happen to the seed before the tiny plant can begin growing? (It must be wet.) You may make a picture in the left-hand corner of your drawing paper of this little plant as it looks when it first comes from the seed, then we shall remember how the morning-glory began life.

At the same time that the children planted their seeds, the teacher planted a quantity in a box by themselves. As soon as the plants in her box begin to break through the ground, a few are taken up and changes noticed by the children. Where is the jelly? (The seeds have used it up. The plant has little roots now and they have gone to work.) [Drawings are made at each stage of the plant's development.]

As soon as the leaves are above ground they are compared in color, size, and shape with the same when in the seed. Look closely between the two 
leaves. What do you see? (A little green dot.) We will watch and see what becomes of it. [They will find later that this "green dot" changes into a leaf.] Only one? Is its shape the same as that of the two? Draw the two leaves side by side on the board.

But this was not all that the "little dot" contained, for they see a small bud pushing right past the leaf ; and what has it? (Another leaf and a bud.) On which side of the stem does this leaf grow ? (On the side opposite to the other.) [Later the children find that the leaves all grow out in this way, - first, one on one side, then one on the other. They admire the beauty of the shape of the leaf and its delicate texture. They notice the veining and illustrate at the board.] Why does it have these veins? (They are the troughs through which the sap passes to all parts of the leaf. They also hold the leaf out, giving it its shape, and allowing the sun, air, and moisture to reach all parts of it.) But why are the vines stretching out their arms to us so pleadingly? (They wish us to help them to stand.) What shall we do for them? (Give them strings for support.)

[After a while the children notice something growing in the axils of the leaves.] What is it ? We will 
watch it and see. Some of these turn out to be branches, others flowers.

[The flower buds are watched carefully from the time they are big enough to be seen until they open and close, and drawings are made of them, showing how they look at different stages of their growth.] How long do they remain in blossom? Mark certain flowers and find out. (From morning until afternoon.) Will this same blossom open again to-morrow morning? Look and see. Can you tell by the looks of a closed flower whether it has blossomed or not? How? Picture, side by side, a bud that will open in the morning and one that has opened and closed. What becomes of the flower that is through blossoming? How long does its pretty dress - the corolla - remain on the vine after it is through blossoming? Watch and see. Why does it fall off? (It is of no more use.) What was its work?

Let us look at this fresh dress. (It is all in one piece, but you can see where five pieces were put together to make it. The seams show.) Let us open it and look at the inside. (The stamens are fastened to the lower part of this dress. There are five of them, one on each piece of its dress.) And do they fall off with the dress? (Yes.) Are they 
not leaving before their work is done? What is their work? They bear the pollen that makes the seeds grow. Where are the seeds? Do the stamens shed their pollen before falling? Notice the open flower and see if they do. How does the pollen reach the seeds? (It falls on the stigma and passes down the style to the seeds; or the bees leave pollen which they have gathered from some other morningglory on the stigma, when they go into the flower for the nectar which is at its base; or the wind blowing carries the pollen from one flower to another.) Did the sepals fall with the corolla? (No, they stay to protect the seed pod.)

The children watch the growth of the seed pod on several flowers which they may select. They see that finally the style dries up, only a small portion of it remaining. Is its work done? What did it have to do? Notice how long a time elapses after the blossom opens before the seeds are ripened. What happens when they are ripe? (Three doors open into three little rooms, in each of which dwells snugly two three-sided seeds. These seeds drop out when the plant is disturbed.)

Now we have found out how the seeds happen to have such queer shapes, - six of them were packed 
I52 NATURE STUDY LESSONS FOR PRIMARY GRADES

closely in a little, round, three-roomed house. What other shape would have packed so well?

\section{IV}

\section{THE COMMON BLUE VIOLET}

At the beginning of the spring term, or at the close of the winter term, the children are asked to look for violets and see who will be first to find one.

As soon as violets become plentiful the children are asked to notice carefully what kind of home they live in. Is it moist ground or dry? Is it in the shade or in the sun? In the woods or out? In company with what other flowers?

Did any of you know exactly where to go to look for violets this year? How did you know? (They grew there last year.) Did they grow all winter? When the snow was off the ground could you see them? (No, the frost killed the leaves in the fall.) Did it kill all of the plant? (No, the root lived through the winter.) How was it protected from the cold? (It was covered with soil; above that were dead leaves, and over all the snow.) Is snow warm? How could it keep the violets warm? (It shut out the cold air and kept in the warmth.) 
Did you look for violets at all before they came, this year? Were there any promises of violets? (The leaves.) Can you think of any reason why the leaves should come first? (They make a pretty home for the flower. They stand around it like little soldiers, ready to protect it.) But that is not all. The leaves are the plants' kitchens, in which all the food is prepared for the flowers and the whole plant as well. The little flowers must have food or they could not grow, so the leaves come first and get the food ready for them. Can you " see the work going on in the leaves? (No, the preparation of the food is made in a very quiet and orderly manner.)

Where does the food which is prepared in the leaves come from? (The roots get it from the ground.) Have you ever noticed the roots of the violet? I have a plant here with its roots washed so that you can see them plainly. Which are the working roots? (The very small ones.) What must these roots have through which to take their food? (Mouths.) Where are their mouths? (All over the tiny roots.) Can you see them? (No.) What kind of food can be taken through such little mouths? (Water.) If you put a little salt or soda 
I54 NATURE STUDY LESSONS FOR PRIMARY GRADES

into water, what becomes of it? (It dissolves so we cannot see it.) Could the plant take anything but water through its tiny root mouths? (It could take other things if they were dissolved in water.) It does this. We do not know all of the things that it takes in this way.

How does this food reach the leaves? (It first passes along to "the large root," then up the stem to the stalks of the leaves, on through the large veins in the leaves into the smaller ones, and so on to all parts of the leaf, where it is prepared as food and then sent to all parts of the plant to feed it.)

What furnishes the heat for preparing the food? (The sun.) Yes, the food cannot be made ready unless the sun helps, and so when the sun goes down the work in the leaves ceases. You have noticed that when your mother is cooking, steam arises from the kettles or saucepans. Does steam arise from this food as it is being prepared? You may place several fresh violet leaves under this glass, look at the glass occasionally, and tell us tomorrow what you noticed. On the inside of the glass will be moisture. From what did this come? Can you see the holes through which it came? (No, they are too small to be seen.) Through these 
tiny holes air goes into the leaf and mixes with the food from the roots before that is fit for the plant to eat. When the food is all ready what becomes of it? (Some of it goes to all parts of the leaf, some to the roots, and some to the pretty blue blossoms.)

You said that there were no leaves in the winter. When did these leaves come? How could they grow when there were no leaves in which to prepare the food for them? (Last autumn, before Jack Frost killed the working leaves, this "large root," as you call it, packed up enough prepared food to feed the roots and leaves this spring, until they got well started at their work and could feed themselves.)

Let us look at this trunk in which the food was packed last autumn. Why do you call it a root? (It looks like one. It grows underground.) What do we find growing from it here? (Leaves.) [The teacher should have a number of different plants in the class.] From what do the leaves on this plant grow? (A stem.) On this? (A stem.) What do we call this part from which the leaves and flowers grow? (A stem.) What shall we call this, then, from which the violet's leaves and flowers grow (pointing to the root-stock)? (A stem.) Since 
I56 NATURE STUDY LESSONS FOR PRIMARY GRADES

it grows under the ground what name might we give it? (An underground stem.)

How did the little leaves look when they started up from this stem to get a peep into the great world, where they were to make ready a home for the flowers? Here are some on this plant which I took up. (The stalk sticks its back up through the ground first, as if to make way for the little leaf blade. Then it comes through with the blade bent over so as to lie close to the upper part of the stalk.) Look closely at the little leaves. (They are rolled tightly from both edges toward the midrib so as to get through the ground without being torn or broken.) And does it unroll suddenly? Notice the bases of the half-grown leaves.

What shape is the leaf? Draw it on the board. Does the shape of the leaf help it any after it is grown? [Sprinkle some water on a leaf of a growing plant. It is well to have some growing in boxes in the house.] What do you see? (The water gathers in the center of the leaf and runs down the little trough in its stalk.) Is that well or not? (It carries the water directly to the roots, where it is needed.) What does the water do? (Dissolves solid food which it finds in the earth, then is taken 
in by the little roots, goes to the leaf, and is mixed with air and moisture coming through the tiny holes in the leaves.)

And while the roots are working away and the leaves are so busy, what is the little flower doing? (Growing.) How does it look when you first see it above ground? Picture on the board. What changes do you notice as it grows older? (The stem lengthens, lifting the bud higher and higher into the air and sunlight. The bud grows fuller and longer. At last the green blanket that covers little Violet is pushed aside, and we see her blue dress.) Notice how her dress was folded while she was wrapped in the blanket. Did it get wrinkled? Do you think you could fold a dress and pack it so tightly and have it come out without a wrinkle? What becomes of the green blanket? Can you see it on your flowers? It still protects Violet. Her dress is very delicate.

Do all violets wear dresses of the same tint of blue? (Some are dark and some are light.) Do they ever wear any other color? (Some violets are white, some are yellow, and some are purple.) Is the dress in one piece? What are the pieces called? (Petals.) Are they all of the same size and shape? (The 
lowest petal is a little larger than the others, and it has a little pocket behind.) Let us see if we can find anything in this pocket. [This can better be shown with a large pansy.] We will cut the pocket off. Now pinch it. Taste. What do you find? (Honey.) We will call it nectar. Why is the nectar there? What would like it? (Bees and other insects.) Have you ever seen any insects about the violets? Watch closely and tell all that the bees or other insects do. Later the children will very likely have discovered that the bee alights on the lower petal, then thrusts in his "long mouth" proboscis - and drinks in the nectar. Notice carefully the path which the proboscis of the bee takes in going to the nectar. There seems to be a path on purpose for it right through the middle of the lower petal, and there is a hedge along both sides of this road. What is this hedge? (A thick beard of short hairs running down the two petals on each side of the flower.) Take this fine stalk of grass and let it follow the road which the proboscis of the bee follows. Then look closely at the grass and tell what you see. (There is pollen on it.) Where did it come from? What is it good for? (To feed the tiny seeds so they will grow.) Let us look 
closely at the home of these seeds. Where shall we find them? [Each child has a flower and finds the pistil.] Where are the little seeds? How is the pollen to reach them? (It must fall on the sticky top of the pistil and pass down through that tube to the seeds.) The sticky top is the stigma and the tube is the style.

Watch one clump of violets at or near your home this spring. Look for seed pods. Here are some which I gathered last summer. Let us see who will be the first to find one on his clump.

Look far down among the violet leaves for something that grows up from the underground stem about which we have not spoken. Tell about it to-morrow. [The next day the children are questioned in regard to their discoveries. They will tell of queer little three-sided buds, of roundish, hard balls, something that looked like the flowers but had no petals, etc. The teacher should have some of these apetalous flowers in the class room, showing different degrees of development. It will be easy to find other seed pods also.] What are these? (Queer little flowers with no petals.) Why do they not come up where we can see them? (They have no pretty petals to show.) Have they borne 
seeds down here in the shade? (Some of them have.)

Here is something still stranger about these queer flowers. [The teacher has a plant in the class with soil on its roots.] Look as I open the soil. (There are some of those queer flowers below the ground, and some have gone to seed here without ever seeing the light.)

When the violet pod is ripe, what happens?

(It divides into three parts and opens.) How are the seeds scattered? What becomes of them? We will plant some in this box and see if they will grow for us. Mamie may care for the box this week.

If the underground roots were all to die, might we still have violets? How?

[Review the life of the violet later, starting with the seed.]

\section{V \\ THE WILD ROSE}

The wild rose is in full bloom in June, before our schools are closed, and is a very simple flower for study. The following are some of the points in which the children will be interested:- 
It presents no loud color, but passes from pure white, which is somewhat rare, to intense pink, through all the intermediate tints. Not unfrequently we find in a single flower exquisite markings and shadings. Its fragrance, too, is as delightful as its coloring.

When the sun is shining the mature rose spreads wide its petals, catching every ray which comes its way, but when darkness reigns it closes, and says to the world, "Good night." Does it close, also, before and during a storm? Watch and see. The closed flower is as beautiful as the open one. When you have seen one you have not seen all, for there are many different arrangements of the petals in closing, but in each the adaptation is so perfect that one wonders that any other plan could have answered so well. Why should the rose close at night? If we notice the texture of one of the petals we find its two sides quite unlike. The soft, velvety upper side might easily be marred by the dew, while the coarser under side seems better fitted to cope with it. This suggests what may be one reason for closing. Later we may find a better one.

Any child can find out how long the petals remain after the flower opens by watching carefully the 
unfolding of certain buds which he has marked, but he must bear in mind that storms of wind or rain often cut the tender lives short.

Although each petal usually performs its part in closing, occasionally we find one, like a willful child, standing off by itself, rolled up to resemble a bud. Sometimes, too, one little petal will creep out of the bud many hours before the others are ready. It looks too dismal to be enjoying its joke.

If there is room in the schoolhouse yard, wild roses might be planted there. Here the children will discover many interesting facts about their appearance and growth.

About the time that the petals fall, the stamens change their bright color for a dark brown, and later this color gives place to black. Their work is done, although they do not pass out of sight. The only part of the rose now especially noticeable is the green seed cup with the sepals fastened to its rim, and falling back over its sides. We had noticed this cup but little when the petals stood about and above it, but it has been growing quite rapidly all of the time. Why should this cup remain while the petals fall and the stamens fade? There is not much more beauty to it than 
to a little green apple, which it much resembles. We will open one of these cups - a large one. Inside we find a number of shining yellow seeds. They form a circle around the inside of the cup. All are closely packed together. The outer seeds are rounded on the outside. There is no definite number of sides to each seed, they differ considerably in shape, and we find, too, some seeds that seem to be dried up. Why is this? We will go back a little. The children have noticed that when they touched the stamens, pollen covered the tip of the finger. The little pollen sacks have burst and the pollen is free. Much of it falls on the little green cushion in the center of the flower. By opening one of the smaller cups it will be seen that this cushion is the feathery top of many small styles which reach down to the seeds. The pollen touches a little seed and says, "Wake up and grow," and the seed obeys. The ovules that did not develop into seeds failed to receive the message, so they did not grow. The petals need to guard the pollen that its seed children may thrive. How does the closing of the rose at night help? Why is it well that the petals are so delicate on the upper side? 
I64 NATURE STUDY LESSONS FOR PRIMARY GRADES

How long a time the seeds grow before ripening can be learned by the children by recording the time of the falling of the petals on a few marked roses.

As the seeds grow the little cup which holds them grows. At last, when they are ripened, the cup proclaims it to the world by its changed color, now a bright red. But this is a covered cup. How are the seeds to get out into the world? Has the plant been working so hard for nothing? "That red cup looks very attractive," says birdie, and down it pounces upon it, breaking the cup and scattering some of the seeds, while it eats greedily from the broken cup. So the rose feeds the birds and the birds free the seeds. Nature's children are everywhere helping one another.

\section{VI \\ TREE BUDS \\ (A SPRing Study)}

There are wonderful discoveries to be made by watching the development of the tree buds in the spring.

Sometimes twigs are put into glasses in the schoolroom early in the season, before the buds begin to 
swell. They can be watched here by the young children much more advantageously than out of Cloors, as oftentimes the branches of the trees are so high that the children cannot see the buds well. It is best to take but few twigs at a time.

Watching the sycamore twigs, a little green ball appears upon one of the side shoots. We are sure it must be a seed ball. It has a white stem about three fourths of an inch long. On each of two opposite sides of the ball is a leaf, growing from its base. Between the ball and each of these larger leaves is a tiny leaf, making four in all. The ball grows quite rapidly, then becomes fluffy. It turns gray - what can this mean? Now showers of pollen are falling from it every time it is disturbed. Are there not seeds, too? (No, the stamens drop off, leaving a white, woolly ball. It turns brown, dies, and falls.)

Now a ball resembling the one previously described grows from a terminal bud. It has a light green stem over an inch long. It is surrounded by leaves as was the other ball. It grows and grows, but sheds no pollen. It is the true seed ball.

The staminate and pistillate blossoms of the balm of Gilead tree grow on separate trees. We 
have twigs from both trees. The staminate blossoms come out dark red, dotted with white. Further observation shows us that these "white dots" are scales which separate the blossoms. They are packed as carefully as if they were delicate china. These scales fall out as soon as the blossoms expand. When the anthers burst, the flowers turn yellow, then a dirty brown. At last they fall. The seed catkins are green, and are sometimes over eight inches long. Their maturing can be followed on the trees.

What do the buds of the plum trees contain? (Three or four flower buds each.) Naturally we look to the cherry tree, expecting to find the same thing true of its buds, but here we find clusters of little green knobs. The central bud develops into a twig, the others into blossoms. Which one is the apple bud like? When its brown bud opens it discloses a gray velvet hood, which contains a set of five or six flower buds surrounded by six or seven leaves. It is quite different from the others.

The opening linden buds make one think of a child's face with its sunbonnet pushed back. The buds are separated by a long space-sometimes three inches. 
The catalpa buds come out from under the bark of the twig where they have been protected all winter. There are four buds in a circle. What queer leaf scars on the twigs!

The twigs of all the trees are interesting. Each variety has a different method of putting forth its blossoms and twigs, and there are constant surprises for the children. The few examples given above are no more interesting than hundreds of others. There is not a prosy one among them.

\section{VII}

\section{AUTUMN LEAVES AND BUDS}

As soon as the leaves begin to fall, encourage the children to bring beautiful ones to school, the teacher pressing some of them for the decoration of the schoolroom. Ask the children to name the trees from which the leaves come. Notice what tree first puts on gay colors, and have the children note the succession. What tree is soonest bare? What one retains its leaves longest of all? Notice the movement of the leaves in falling. Listen to the sounds which they make.

The trees that wear yellow dresses may be 
grouped together, also those that wear dresses of red, bronze, brown, red and yellow, etc. Do all trees that send off their leaves dress them beautifully before they go? What trees have leaves that shrivel up when the frosts come?

2ji You haveihad a story about a little leaf that worried a great deal [ "The Anxious Leaf" ", by Henry Ward Beecher]. n About what did it worry? (For fear the wind would pull it off and throw it down on the ground to die.) Is the wind doing that with any leaves now? Do they fall easily? Could the wind always pull the leaves off so easilyy? (No, not in the spring and summer.) You may shake the little branch that I brought in. (The leaves come fluttering down.) Let us / see if 1 wes can find out/ why the leaves fall so easily now: aWhylis it, do you think? (")They forget to bang on "ron "They are toose." "Something is growing up between the ldeaf and the branch, andos the leaf scant ic reach around it i) Look clbsely: at that something w What is it ? r (A tiny o budk) s sWill dit/fall off ? 5 oWhy do you think it will not

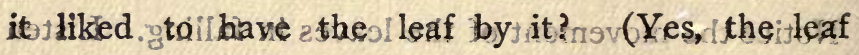
clasped it and kept it warm, sand dry and out of the sight 20 f buigs which might eat such a tender 
thing.) It is true that the buds need the leaves when they are so tiny, but they do not push the leaves off. Notice carefully these leaves on the branch. Here is a little fence which has been slowly built up between the leaf and the branch. When the fence is done, the leaf drops. But this fence is never built up too fast. The leaves, all through the summer, are working away, for they prepare all the food which the tree needs. When the little fence is begun, the tree ceases to need much food and so stops growing. Instead of using now the food prepared by the leaves, it packs it away in its trunk and branches, for it will need it in the spring; and when the leaves have furnished the tree all the food it needs, their work is done, and they are ready to go, and just at that time the fence is finished.

Of what use are the leaves after they fall? (They cover the roots of the plants and protect them from the cold. The snows and rains cause them to decay.) Of what use are the decayed leaves? Bring leaf mold to the class - coarse and fine. How is it made? Of what use?

[This is probably as deep as we shall care to go into the subject with little children who have just entered school.] 
You have spoken of the leaf caring for the bud. Why should it care for it so tenderly? Of what use is a bud? Let us see what is in this little cottonwood bud. (The outside is sticky.) Why is that? (To protect it from the rain and snow and to keep bugs from eating it.) We will take off this waterproof coat very carefully. What do you see here? What do these coats do? (There must be something very valuable inside which these coats are keeping safe.) And inside these soft wrappings what do we find? (Some tiny leaves - a little twig.) What are they doing here? (They are lying in their warm bed, cuddled closely together, waiting for spring. When the weather begins to get warm in the spring, the wax on the outside will melt and the buds will swell so that their covers become too small, then they burst open and finally fall.) Why do the buds not open now? (They would freeze in the winter, so the tree gives them very little food-just enough to keep them alive, but not enough to make them grow.)

Open other buds; some will be found to contain flowers. Notice the difference in the shapes of the twig buds and flower buds. [The flower buds on many trees are short and round, while the twig 
buds are long and pointed.] By noticing the opening of the buds in the spring these same facts can be learned without destroying the buds.

Was it not too bad for the leaf to leave the little bud? (No; the bud does not need it longer, it is covered up so well. The leaf stayed with it until it had on all its covers, so the little buds do not need the leaves, and the tree does not need them to prepare its food.) But would it do any harm for them to stay? (Yes, the snow might gather on the leaves and break the branches with its weight.)

Do you think you would find buds on all these trees that are losing their leaves? Look and see, and find if the leaves and flowers of the different trees are wrapped up in the same way that those on the cottonwood are wrapped.

It is advisable when beginning the study of buds to center observation chiefly upon two or three kinds of trees, as hickory and cottonwood.

\section{DEVICES IN IDENTIFYING LEAVES}

I. Have a package of leaves of several different varieties for each child. Give the name of a leaf and have each child show a leaf of that name. 
2. Have a number of leaves on the table. Call rapidly on the children, one at a time, to select the different leaves you name.

3. A child names a leaf, calling on another child to select it; the school approve the choice by saying, e.g., "Yes, Earl," or "No, Mary." If the child called upon selects the correct leaf, he names a leaf for another to select, and so on.

4. A child stands before the class with a package of leaves; holding up a leaf, he says, e.g., "This is a sugar maple leaf," etc., until he names one incorrectly. The first child who detects the mistake takes his place and names leaves until he misses one, and so on.

5. The children are each supplied with several varieties of leaves. They examine closely and describe. They name the characteristics, e.g., of the elm, the scarlet oak, the linden.

6. (a) The teacher describes a leaf; the children name it from her description. (b) A child describes; the others name.

7. All the pupils close their eyes. Each is provided with a leaf, which he names by feeling it.

8. A child makes a drawing of a leaf at the board. The children name from the drawing. These sketches are put on the board rapidly. 
9. A child draws, for example, an oak leaf; the children criticise the drawing.

ro. Beautiful autumn leaves are mounted on panels. These panels are strung together and hung upon the walls at the top of the blackboards. A pupil points to the leaves and names rapidly.

II. Leaves of various trees are given to the children. Seeds of these same trees are also given to them. The children arrange the leaves on their desks and place upon each leaf the corresponding seed.

12. Cut slips of cardboard five by ten inches. Upon each slip print, or write with a brush, the name of a tree. Scatter these slips about the room, placing them on the ledge of the blackboard.

Upon the table place leaves of the trees named upon the cards.

A child is asked to pick out a leaf and place it by its name. The class say, "Yes, _- (calling the name of the child), if the leaf is correctly placed, or "No, _ , if the leaf is placed by the wrong slip. See which one can match correctly the largest number of leaves and cards.

To vary the exercise, slips may be chosen to match the leaves. 
[This may be used for bird identification by substituting mounted specimens or colored pictures of birds for leaves, and using the names of birds on the slips.]

\section{LEAF GAME No. I}

The children play leaf games, e.g. the following, suggested by Lula Ward:-

"Oak, elm, and walnut, standing in a row, Standing there so straight and tall,

With leaves all showing so.

Now one away is skipping, as fast as she can go.

Name her quickly, Florence, and you'll be in the row."

\section{Explanation:-}

Each child in the class has a leaf pinned upon his breast. Three pupils are called to stand out in front of the class; the names of the leaves which they wear are substituted for the names given in the first line of the little rhyme. As the fourth line is sung, one of the three children skips away. If the child whose name is called in the last line can give the name of the leaf which the former child wears, he takes his place in the row in front of the class. (He wears a leaf of some other tree.)

The little rhyme is sung by all the children except the three in the row. 


\section{LEAF GAMES Nos. 2, 3, AND 4}

In "For Grace and Pleasure" are three games which may be used in connection with the identification of leaves; see "Leaves in the Wind," p. 7, "The Barberry" (or other plant), p. 28. Substitute the name of the tree from which a leaf came, e.g. maple tree, in place of "September leaves," p. 7.

\section{LEAF GAME No. 5}

Each child has the leaf of a tree pinned upon his waist. The children form a circle and sing this song as they move about in the ring:-

"Here we go round the — tree, the — tree, the - tree; Here we go round the - tree,

So early in the morning."

(Sing to the tune of "Here we go round the mulberry bush.")

As soon as the name of the tree is sung, the child who wears a leaf from that tree steps quickly into the ring. If he fails to respond, through inattention or lack of identification of the tree by its leaf, he steps out of the ring. If he recognizes his leaf name when called later, he dodges into the center of the ring and is again in the game. 
LEAF GAME No. 6

A leaf is pinned upon each child's waist as in the previous game. The children sing:-

"Fly away, fly away,

Dear little — leaf, fly away;

Over the brown fields dance and play,

But come back to see us again to-day.

Come back, — leaf.

Come back, — leaf."

(Tune, "Milkweed Babies," Primary Education, October, 1902.) - Eleanor Troxell.

As soon as the name of a leaf is sung, the child who wears that leaf flies about the room. The children at their seats sing "Come back," etc., beckoning at the same time to the "little leaf" flying about.

\section{VIII}

\section{A NUT GAME}

Different kinds of nuts are scattered about the room. One of the children who knows the names of all the nuts is the mother squirrel. The other children are the little squirrels. The mother sends one little squirrel out to find walnuts, another to find beechnuts, another to find hickory nuts, etc. If one brings back the wrong nut, he must return it to the 
place where he found it, and another little squirrel is then sent with him to find the nut which he was asked to find. See how many can find all the nuts called for, without making a mistake or having to be helped.

\section{A RIDDLE}

As soft as silk, as white as milk, As bitter as gall, a thick wall, And a green coat covers me all.

\section{IX \\ THE APPLE \\ (A Winter Study)}

How many like apples? What kind do you like best? (The child does not need to name the variety, although if he knows its name it would be well to give it. The children's answers will reveal the fact that sóme like sweet apples; others, sour apples, juicy apples, mealy apples, apples that have a spicy taste, etciWNearly every taste can be suited in apples, therefore many people eat them.)

Is Do yopreat the whole apple? What part do you thitow sway ?t (The skin, perhaps, and the core.) 
Many people, however, eat the skin. Did you ever eat a core? How do you like it? What trouble does eating a core sometimes give you? (The scales of the cells stick in the throat.) What is the use of these scales? Let us examine these apple cores. (The scales make rooms for the seeds.) How many scales does it take to make one room? How are the scales fitted together? How many seeds inside a room? (The children will find that the numbers differ.) Describe the inside of the room. How are the seeds packed in it? (They will notice that the pointed end of every seed points toward the center.) Of what use are the scales to the seeds? (They shut them away from the rest of the apple, keeping them safe, no matter how juicy the apple or watery the core.) Give to each child an apple cut horizontally through the center. How many rooms in each apple core? Notice how the five rooms are arranged about the center. Show at the board.

With what are these rooms surrounded? Of what use is the pulp to the seeds? (It shuts them in until they (and the pulp as well) are ripe.) What other uses for the pulp?

Now it is strange that the part of the apple that you do not care about - the seeds in the core - the 
apple tree cares most for and has taken the greatest of pains to protect. Can you think why? (That the seeds may make more apple trees.) Is it or is it not well for the seeds that you like the pulp? (By eating the pulp from the core the apple seeds are set free; they could not grow inside the apple.) Why is it well for apple seeds that there are many different kinds of apples? (They suit the different tastes of different people, and so a large number of people all over the country are setting apple seeds free.) What other uses are made of the pulp? (It is stewed, fried, made into pies, dumplings, salads, jelly, preserves, etc., and it is dried.)

What besides people like apples? Do the chickens eat the seeds? Find out if this is so. What part of the apple do the pigs eat? What eat the apples that are left on the trees in the winter?

How do the apples make known to us that their seeds are ripe and ready to be set free? (Their bright colors - red, yellow, green, and russet-brown attract us.) How can the green apples attract us while the leaves are still green? (They are glossy and are of a different shade of green from the leaves.) What gives the color to the apple? (Its skin.) Describe the skin. (It is thin, smooth, glossy, tough, 
and somewhat elastic.) Of what use is it other than being the sign which says, "I am ripe" ? (It holds the pulp in shape, keeps it from being broken and rubbed off, holds in the juice.) Why is it well that it is somewhat elastic? (It does not readily crack when the apple falls.)

How is the apple fastened to the twig? To what part of the twig is it fastened? Notice the stem. Chew it a little. Of what is it made? (Of many little threads or fibers.) These are much stronger than one large single piece would be.

What color are the apples before they are ripe? Why do you think this is well? (They are of nearly the same shade as the leaves, and so are not noticed much by people who are passing and by birds.) What is the color of the seeds of an unripe apple? How does the pulp feel?

How do the apples begin life? We will find this out next spring. We will begin watching a tree now - and look at it every week until we find some little apples. What do you see on the tree now? (Buds.) Describe the buds.

NoTE. - Before the subject is left, review it thoroughly. Have the children tell all they have learned about the seeds; their rooms; the pulp; the skin; the stem. 


\section{X \\ THE AUSTRIAN PINE}

\section{(A Winter Study)}

Did the Christmas tree surprise you on Christmas eve? What did it bring you that you did not expect? When the presents were all off and the decorations removed, had it any more surprises for you? You did not care for the bare tree, then. This bare tree which is sometimes used as a Christmas tree has greater surprises for you than the presents gave. It is full of secrets which few people find out. Would you like to find some of them out, all by yourselves?

But we must become better acquainted with the tree before we expect it to tell us any secrets, and we will visit one that has not been cut down. What kind of tree was the Christmas tree? Why was an evergreen chosen? What was its name? Do you think all evergreen trees are alike? [The children find out by examining the foliage of different evergreen trees that they differ greatly. Other differences will be discovered later.]

We will visit the tree with the long, stiff needles. I will introduce you to it. Austrian 
Pine, these are my little boys and girls who wish to visit you often.

On this first day the children learn to distinguish the Austrian pine from other evergreen trees by its general appearance. They know it by the shade of green of its dress; by its straight, pointed trunk; by its arms or branches, which extend out nearly straight from the trunk, then curve upward; by several branches starting out from the same circle and reaching out in different directions; by gradual shortening of the branches from below upward. After learning to recognize the tree readily, the children make drawings, showing its general shape. This is the picture of the naked tree as it looked after it had lost its leaves in the story of "The Unhappy Pine Tree." 1 Is it pretty? What gives beauty to the tree? Its dress. And this is a wonderful dress. Let us see of what it is made. [Each child has a small twig.] (It is made of needles. And the needles are put up in bundles, only two in a bundle. The wrapper which holds them together is around one end only.)

1 "Classic Stories for the Little Ones," published by Public School Publishing Company, Bloomington, Illinois. 
Let us look at one needle. [The children measure it.] It is longer than a darning needle and of different shape, being round on the outside and nearly flat on the inside. It is very strong. We can hardly pull it in two. Is it well that the pine tree has such needles? [Refer to the story of "The Unhappy Pine Tree."] Not only goats but caterpillars and insects usually pass the leaves of this tree by. Hail, snow, and sleet cannot injure them much. Why not?

Pull out one pair of needles. [The children find that it is set very deeply and firmly into the twig.] Why is this well? [The children discover that the needles in a package so fit together as to resemble in shape a darning needle.] Where on the twig are they set? Do you like that arrangement? Why? Does the Austrian pine ever lose its leaves as do the maples and oaks? How do you know? When do they fall? Do they fall singly or in pairs? What color are they when they fall? Do you see any such on the tree now? If so, where? How old are the needles when they fall? You cannot tell now. You do not know it well enough yet to find out all its secrets. Now tell all the secrets you do know about the package of needles. Make a drawing of them. What secret has the tree failed to tell you? 
We have been talking about the Austrian pine's dress. Does it wear any ornaments? (The cones.) Where does it wear them? Notice this carefully. Are they all alike? [Have twigs in the class with cones of last summer's growth and others a year older.] Notice color and size of each, the number in a cluster (if you are so fortunate as to find two or three together). Notice cones under the trees and compare them with those on the twig. Do you find on the ground any of the little cones? Why not? Their work is not done. The leaves on the elms and maples did not leave the tree until their work was done, neither will the little cones.

Let us see if we can find out what the work of the cones is. The cones that have seen two summers are chosen. Where on the twig did we find them? Draw the cone when first brought into the room. Draw also the twig with the cone upon it, fixing its place on the twig. [The children notice the queer shapes of the doors with their comical little knobs; they also notice how each door is braced in front by two doors at its side and one before it. The doors are very many, and are closed so tightly that it is with great trouble that we get them open.] Will the cone not let us know what she is guarding so 
carefully? We will not break into her house. We will lay these cones where we can watch them. [If possible, the children should hear and see the doors pop open. This will happen after they have been in the warm room a few hours.] Now that the cone has opened her doors we will look in and see if we can find what secret she was keeping. [The children discover two little seeds behind each door, each with a large wing.] How cozily they lie in the little room! They are well worth guarding. Why? Why were they shut in so tightly? What will open the doors of the cones on the trees? (The sun.) When will they open? What will the seeds do then? How will the wing help them? The tiny cones are placed also in the warm room and left there for some time. Why do they not open?

Some old cones may be found with their doors open. Inside are no good seeds. Why is that so? (The seeds flew away last spring when the warm sun opened the doors.) [The children now make a drawing of the twig with cones of two sizes. They tell the secrets of the cones. They draw a single door with the two seeds, and one seed by itself, and tell the secret of the seeds. A number of seeds are kept for planting when spring shall come.] 
What else do we find on the branch besides leaves and cones? (Buds.) On what part of the twig do you find these buds? Are all of the same shape? [The children find that some are large and pointed, others are round and flat, while others are made up of a cluster of little buds.] Why this difference? Let us see if we can find out. [A pointed bud is first examined. The children notice how the lower scales curve downward. (If kept in a warm room, more of the scales will turn down.) They also notice the great number of coverings.] Are they thick or thin? Soft or harsh? How arranged? All of the same length? How held together? [The pitch shows itself after being kept in a warm room some time.] The covers being carefully removed, the children are delighted to find what they think is a cone. But where on the twig did we find the cones? (On the sides, but this is directly at the end.) What does grow at the end of a twig? Leaves on a stem. What then should you expect to find in this bud? We will put this little bare bud, with a covered one, into this bottle of alcohol. It will keep them fresh. How shall we label it? We will say we do not know what this is. But what do you think it ought to be? It is another secret which 
we can not find out until we know the tree better. What was the first secret kept from us? When may we surely know the secret of the bud? Tell the secrets which you know of the pointed buds, and the one which the tree is keeping from you, but which you think you can guess.

Now, let us see if we can find out the secret of the round, flat buds. [The children find that the outside covers are much like those of the pointed buds, but inside of a few covers they find from five to ten tiny buds crowded all the way around a small, pointed bud. The inside covers are soft and transparent. When uncovered, the children are apt to think they have again found cones.] But where do we find these buds? Do you find such clusters of cones on the tree? [The children notice the resemblance between the pointed bud in the center here and the pointed bud we examined before. They tell what they think this bud contains and what they think may grow from the center bud.] The naked, tiny buds are placed in alcohol with a bud as we found it on the tree. What shall we label it?

There is still another kind of bud, a clustered bud, not covered to appear like a single bud as was the preceding. Does it contain a pointed bud? 
Where on the twig was it found? On what kind of twig? [These buds are also preserved.] Are there any other kinds of buds? [The bottles of buds are numbered, and the children from now till spring frequently review their knowledge of these buds and their suppositions in regard to them.]

This branch on which the needles and buds and cones grew may have something to tell us. Notice carefully the curled-back covers of this pointed bud. Do you find anything like this on the twig? Where? How do you suppose those scales came there? [The children are quick to catch the idea that the bud left them when it began to grow.] What did it grow into? (A little twig.) How long? [The children usually suggest that that is exactly what this pointed bud will grow into.] If so, what must that be in the pointed bud? (A little twig packed away in a very small trunk.) And what was the green that you saw in the bud? (The leaves.) How long did it take this three or four inches of twig to grow? (A year.) [The children see that it must have taken many years for the tree to become so large at that rate of growth.] Look back and see if you can find where another bud started. How old is that part 
of the twig? Find another year's growth. Another. Still another. Are there leaves on last year's growth? On the second? On the third? On the fourth? On the fifth? [Sometimes they will find the leaves mostly or wholly gone from the five years' growth, and sometimes there are leaves on the six-year-old twig.] Where did the brown leaves go? How old when they fell? What did they leave behind to show that they had been here? (A queer little three-cornered card, often turned down at the top.)

Notice the twigs with the round flat buds, or the large clustered ones. [The children find the year's growth there to measure only from three fourths of an inch to an inch.] Why so much shorter than on twigs with long pointed buds? (Its food had to be divided with those little stranger buds that clustered around it, so it could not grow so much.)

Did you ever try to break a twig or a branch from an Austrian pine? Was it easily done? After a snow storm the teacher takes occasion to call the attention of the children to the beautiful but sad appearance of the tree. Its branches no more reach up toward the sky, but droop to the earth. It seems as if the tree could never hold itself up 
as it did before the storm. The children make a drawing of it now and compare this picture with the first one drawn. Why does not the heavy snow break off the branches? Show sections of the tree where branches have grown out, that the children may see how well the tree guards against such accidents.

What secrets have you found out about the twig and branch? You may draw a branch of seven years' growth. [If they have observed carefully they will put no needles on the oldest growth, and perhaps none on the sixth or fifth.] But here are side shoots. From what did they come? Notice where they start out. From what buds did they come? Can you tell? Then we must also find this out next spring. Can you tell yet from what the cones will come? We shall have to watch the tree closely next spring, else it will keep this secret from us. Now what are all the secrets which the Austrian pine is keeping from us this winter?

Do you like this tree? What do you like about it? It is a useful tree, too. For what is it used? (For lumber.) [Children name articles made from pine.] (The birds come to its shelter when they return early in the spring. The winter birds - 
crows, owls, etc., - spend much time in its branches, which shelter them from the cold winds.)

As a summing up of many facts discovered in regard to the Austrian pine, and a reminder of their pleasant acquaintance with it, a collection of the following may be mounted on stiff cardboard: A pair of green leaves, a pointed bud, a round flat bud, an open clustered bud, cones of one, two, and three seasons' growth (the cone of two seasons will need to be varnished to keep it from opening), a cone scale, two seeds, a bare twig, a twig with leaves, cross and vertical sections of the wood. 



\title{
METHODS OF ELEMENTARY EDUCATION
}

\author{
BY DR. CHARLES A. MCMURRY \\ COVERING ALL GRADES OF THE COMMON SCHOOL
}

THE ELEMENTS OF GENERAL METHOD • • 90 cents THE METHOD OF THE RECITATION (By C. A. and

F. M. MCMURRY) • • • • • • . 90 cents SPECIAL METHOD IN THE READING OF COMPLETE ENGLISH CLASSICS • • • • 75 cents SPECIAL METHOD IN PRIMARY READING AND ORAL WORK WITH STORIES . . . . 60 cents SPECIAL METHOD IN GEOGRAPHY . . . 70 cents SPECIAL METHOD IN HISTORY . . . 75 cents SPECIAL METHOD IN ELEMENTARY SCIENCE. 75 cents SPECIAL METHOD IN ARITHMETIC

\section{IN PREPARATION}

SCIENCE LESSONS FOR PRIMARY GRADES

SPECIAL METHOD IN MANUAL TRAINING AND CONSTRUCTIVE WORK

SPECIAL METHOD IN LANGUAGE

\section{TWO NEW BOOKS ON GEOGRAPHY}

\author{
By Dr. Charles A. McMurry
}

\section{EXCURSIONS AND LESSONS IN HOME GEOGRAPHY} TYPE STUDIES FROM THE GEOGRAPHY OF THE UNITED STATES. Each 50 cents, net.

Two new books for the use of both teachers and pupils. The material provided in the Excursions and Lessons constitutes the introductory lessons in geography for third and fourth grades. It is the geography of the home and the neighborhood. The illustrations are taken from many different localities, and are typical of various parts of the country.

Type Studies is designed to illustrate in some detail the second stage of geography study, following the Excursions and Lessons. The purpose of the simple type studies given is to introduce children to the geography of our own country. This volume also is appropriately illustrated. 


\section{A HISTORY OF EDUCATION IN THE UNITED STATES $\$ 2.00$ Net}

\section{By EDWIN GRANT DEXTER, Ph.D.}

Professor of Education in the University of Illinois

This new work has been prepared in the belief that the greatest need of the student of our educational history is a considerable mass of definite fact upon which to base his own generalizations, or with which to interpret those of others, rather than extended philosophical discussions of historical trend. Current educational literature is rich in the latter, though comparatively barren of the former. The present book deals, therefore, with the fact rather than with the philosophy of education in the United States. It contains an exceptionally valuable equipment of references and bibliographies.

\section{THE PHILOSOPHY OF EDUCATION \$1.50 Net}

\section{BY HERMAN HARRELL HORNE, Ph.D. Assistant Professor of Philosophy and Pedagogy in Dartmouth College}

This volume is a connected series of discussions on the foundations of education in the related sciences of biology, physiology, sociology, psychology, and philosophy. It is not another of the many current manuals of practice, but a thorough-going interpretation of the nature, place, and meaning of education in our world. The newest points of view in the realms of natural and mental science are applied to the understanding of educational problems. The field of education is carefully divided, and the total discussion is devoted to the philosophy of education, in distinction from its history, science, and art. The conceptions of evolution, society, and genetic psychology shed their light upon educational phenomena, yielding in the end a comprehensive definition of what education is. The various conflicting modern educational opinions are organized to a considerable extent, and are made to appear as partial truths of a common system. The whole is suffused with the spirit of an idealistic philosophy in which education is finally made to yield its ultimate meaning as to the origin, nature, and destiny of man. 
BUTLER'S THE MIEANING OF EDUCATION . • \$1.00

CHUBB'S THE STUDY AND TEACHING OF ENG-

LISH

I.00 net

CUBBERLEY'S SYLLABUS OF HISTORY OF EDUCATION.

DE GARMO'S INTEREST AND EDUCATION • $\quad$. .00 net DUTTON'S SOCIAL PHASES OF EDUCATION • 1.25 HANUS'S EDUCATIONAL AIMS AND VALUES . 1.00 HERBART'S OUTLINES OF EDUCATIONAL DOCTRINE • • • • • • • • • $\mathrm{C} .25$ net HERRICK'S THE MEANING AND PRACTICE OF COMMERCIAL EDUCATION • • • • 3.25 net KING'S PERSONAL AND IDEAL ELEMENTS IN EDUCATION . • . . . . . . KIRKPATRICK'S FUNDAMENTALS OF CHILD STUDY . • • • • • • • . r.25 net MONROE'S SOURCE BOOK OF THE HISTORY OF EDUCATION • • . . . . . 2.25 net OPPENHEIM'S MENTAL GROWTH AND CONTROL • • • • • • • • .

DEVELOPMENT OF THE CHILD . . . 1.25 net REDWAY'S THE NEW BASIS OF GEOGRAPHY 1.00 net ROWE'S THE PHYSICAL NATURE OF THE CHILD . . . . . . . . . 1.00 ROYCE'S OUTLINES OF PSYCHOLOGY . . . $\quad$ x.00 net SHAW'S SCHOOL HYGIENE . . . . . 1.00 net SMITH'S TEACHING OF ELEMENTARY MATHEMATICS 


\title{
A MODERN SCHOOL
}

\section{\$I.25 Net}

\author{
By PAUL H. HANUS
}

\begin{abstract}
Professor of the History and Art of Teaching in Harvard University Author of "Educational Aims and Educational Values," etc.
\end{abstract}

The chapters of which this volume consists, except the last, deal with various phases of one central theme: the scope and aims of a modern school, and the conditions essential to its highest efficiency. The last chapter offers some testimony on the working of the elective system, - a contemporary question of great importance to both schools and colleges, - but the testimony offered pertains only to the college. The first chapter deals specifically with the secondary school; and in it the author has endeavored to extend and strengthen certain conceptions set forth in his earlier book. The next seven chapters contain a fuller treatment of certain topics than was appropriate or expedient in the first chapter, and discuss the internal and external conditions essential to a high degree of success in the work of any school.

\section{PIONEER HISTORY STORIES}

PIONEERS ON LAND AND SEA

PIONEERS OF THE MISSISSIPPI VALLEY

PIONEERS OF THE ROCKY MOUNTAINS AND THE WEST $\} \begin{aligned} & \text { each } \\ & \text { each }\end{aligned}$

\section{BY DR. CHARLES A. MCMURRY}

This series provides excellent supplementary reading matter for schools of from the fifth to the eighth grade. In these volumes is told the story of the pioneer life of all sections of our country, from the epoch-making voyages of Columbus to Major Powell's marvellous journey through the Grand Cañon of the Colorado. The stories are complete and interesting, making the experiences of pioneer life as graphic and real as possible. Indeed, the text is made up largely of source materials. These narratives, which are accompanied by admirable maps and illustrations, constitute the best of all introductions for children to the history and geography of the country.

\section{THE MACMILLAN COMPANY}

64-66 Fifth Avenue, Now York

CHICAGO BOSTON

ATLANTA

SAN FRANCISCO 



\section{DAY USE}

RETURN TO DESK FROM WHICH BORROWED

EDUCATION-PSYCHOLOGY

- LIBRARY

TEL. NO. 642-4209

This book is due on the last date stamped below, or on the date to which renewed.

Renewed books are subject to immediate recall.

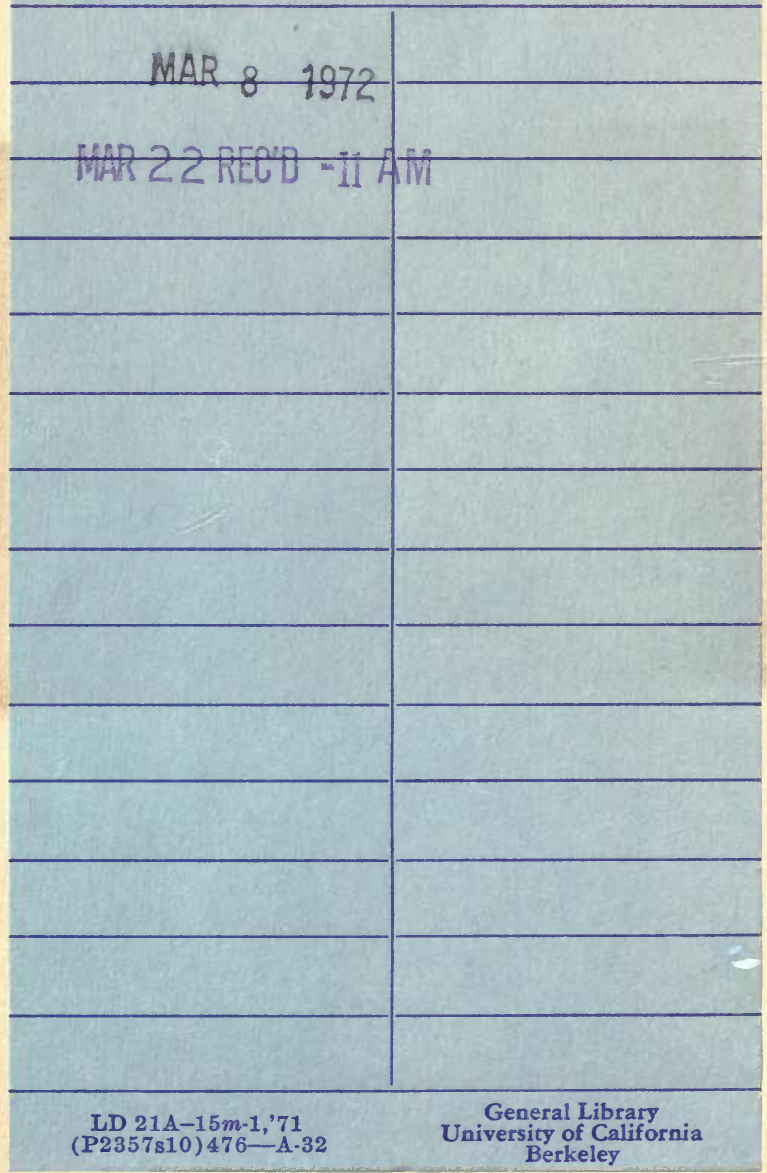


$\angle B / 532$

$\mathrm{M}_{3}$

54.1174

Educ Dept.

UNIVERSITY OF CALIFORNIA LIBRARY 
